\title{
a economia madeireira no colonial tardio fluminense: uma primeira aproximação
}

DiOgO DE CARVALHO CABRAL*

Geógrafo, Mestre em História Social pela UFRJ

\section{RESUMO}

Quase toda cena que tentemos imaginar do cotidiano da sociedade colonial terá, em seu substrato mais sutil,diversos elementos, cuja arqueologia, se feita com minúcia, nos levará ao ponto de partida inexorável: o lenho da árvore. Se há algum fundamento para falarmos de uma "civilização do açúcar", uma "civilização do couro" ou uma "civilização das minas", também o há, de maneira ainda mais incisiva, para falarmos de uma "civilização da madeira". Que mecanismos econômico-ecológicos sustentavam esse moduns vivendi? $\mathrm{O}$ objetivo deste artigo é traçar um esboço do sistema de produção-circulaçào inadeireiro que conectava o Recôncavo da Guanabara e outras áreas rurais da Baixada Fluminense á cidade do Rio de Janeiro do período colonial tardio (C.1760-C.1830), dando ênfase às condições ambientais, ao padrão de localização das áreas produtoras, às formas de comercialização e às relações sociais de trabalho e de troca.

Palavras-chave: indústria madeireira, comércio interno, sociedade colonial, Rio de Janeiro, história econômica do ambiente

\section{A B S T R A C T}

Almost every scene about the colonial society's daily life one try to imagine will incorporate,-in its deeper subtleness, various elements whose archaeology, if properly made, will lead to the inexorable starting point: the tree's trunk. If there is any reason to talk about a "sugar civilization", a "leather civilization" or a "mining civilization", there is also one still more sharply to talk about a"wood civilization". Which economic-ecological mechanisms maintained chis modus vivend?. The aim of this article is to sketch the general outlines of the timber production-circulation system that connected the Guanabara Bay drainage network and other rural areas of the coastal plain to the Rio de Janeiro city in the late colonial period (c.1760 c.1830), giving emphasis to environmental conditions,location patterns of lumberjack centers, commercialization forms and work and trade social relations.

Key-words: timber industry, internal commerce, colonial society, Rio de Janeiro, economic history of the environment

* O autor agradece as importantes contribuições de Antônio Carlos Jucá de Sampaio, Maurício de Almeida Abreu e José Augusto Pádua,isentando-os, obviamente, de toda responsabilidade por quaisquer equívocos encontrados na versão final do artigo, email: diogocabral@supering.com.br.Submetido: março,2006; aceito:outubro,2006. 
[...] só há riqueza florestal se incorporada na economia, na presença de uma multidão de intermediários, pastores que conduzem os seus rebanhos (e não só os porcos às bolotas), lenhadores, carvoeiros, carreteiros, todo um povo selvagem [...] com o ofício de explorar, utilizar, destruir. A floresta só vale se for utilizada.

FERNANDB RA U DEL.(1997:331)

Desde os tempos mesolíticos, o progresso humano dependeu de arrancar as árvores com que a maior parte da superfície do planeta estava coberta. A história da cultura material do Homo sapiens é, grande parte dela, a história da transformação dos ambientes silvestres em espaços habitáveis. Para construir seu habitat, o homem sempre utilizou, como matéria-prima fundamental, a biomassa lenhosa - isto que chamamos madeira. Mesmo os sistemas agrícolas baseados na queima da mata - uma técnica tão antiga e difundida em todo o planeta, principalmente na faixa tropical - nunca tiveram, como único objetivo, obter solo limpo para a lavoura, mas também fertilizantes para desenvolvêla: a biomassa é incorporada ao processo produtivo na forma de cinzas, matéria orgânica decomposta pela reação de combustão. E, na sua forma não-carbonizada, como lenho, a madeira prestou-se como combustível e material de construção. Os troncos das árvores serviram para construir as casas, os equipamentos domésticos e para aquecer os depilados mamíferos nos tempos de frio. Por tudo isto, disse John Perlin (1992: 25), a "madeira [...] é o herói não reconhecido da revolução tecnológica que nos impulsionou da cultura da pedra e do osso para a nossa época presente".

Todavia, é perfeitamente compreensível que este fato não tenha sido plenamente reconhecido e tomado pelos historiadores como objeto de reflexão, e parece haver duas grandes razões para isto. Em primeiro lugar, a preocupação com a natureza não-humana, "não aquilo que está diante, mas o que nos sustenta" (MERLEAU-PONTY, 2000:4), é bastante recente nas ciências sociais em geral e, mais particularmente, na história ${ }^{1}$.Em segundo lugar, como ressaltou Edoardo Grendi (1998: 257), "o testemunho-documento pode ser excepcional porque evoca uma normalidade, uma realidade tão normal que ela permanece habitualmente calada"; em outras palavras, a madeira parece ter sido um

Em meados da década de 1980, Donald Worster (1984: 16) ainda se queixava de que "há muito pouca natureza no estudo da história", clamando por uma perspectiva ecológica na disciplina. 
dado tão imiscuído na experiência diária dos indivíduos, nas sociedades pré-industriais, que sua importância tendia a não ser explicitada pelos coevos.

Ao olhar contemporâneo, o tema da madeira pode parecer algo obscuro, distante da realidade cotidiana. Mas não o era, em absoluto, para as gerações passadas - pelo contrário, era um assunto extremamente corriqueiro e banal. As árvores foram o principal combustível e material de construção de quase todas as sociedades humanas por mais de cinco mil anos, desde a Idade do Bronze até meados do século XIX. Até essa época, as árvores ainda cumpriam essas funções para a maioria das pessoas que habitavam o planeta (PERLIN, 1992: 25-32) 2. Nenhum recurso natural contemporâneo é comparável ao papel proeminente exercido pela madeira no mundo pré-industrial: era não somente o aço e o alumínio, o plástico e a fibra de vidro, mas também o petróleo, o carvão e o gás. Estruturalmente, a madeira não tinha competidores, já que era a única substância de ocorrência natural que exibia força de tensão, sendo, ao mesmo tempo, extremamente maleável ${ }^{3}$. Na era mo derna, muitos materiais produzidos pelo homem vieram apenas a desempenhar funções que a madeirajá o vinha fazendo até então - e, muitas vezes, sem conseguirem superá-la em eficácia.

A problemática histórico-ambiental é fundamental para compreendermos o que Karl Marx chamou de "falha metabólica", isto é, o desenvolvimento de um sistema assimétrico de trocas entre a cidade e o

'É importante ressaltar que, ainda hoje, a madeira desempenha um importantíssimo papel na geração de energia, principalmente nas áreas rurais pobres do mundo subdesenvolvido.

${ }^{3}$ A estrutura celular é responsável, em grande medida,pelas vantagens da madeira sobre outros materiais estruturais. Na madeira, um número comparativamente pequeno de células contém protoplasma vivo. Na maioria das células, ele desaparece ao longo do processo de maturação, espaço que é preenchido, geralmente,pela água e pelo ar, em proporções variadas. Ocasionalmente, outras substâncias, como resinas e minerais, são depositados nestas cavidades. As células da madeira crescem todas juntas, muito próximas umas das outras, formando um material mais ou menos coerente, mas poroso. As cavidades permitem que as células "cedam", de modo que pregos e parafusos podem, facilmente, penetrar no material, propiciando meios relativamente fáceis de prender dois pedaços. Pelo fato de que, na maioria das madeiras com valor comercial, mais da metade do volume é ocupada por espaços vazios,sua dureza não é tão grande, mas elas podem, em compensação, ser modeladas em várias formas com o auxílio de instrumentos simples e relativamente pouco esforço (KOEHLER, 1924: 2). 
campo, a partir de uma crescente divisão socioterritorial do trabalho (FOSTER, 2005: 218-28). Neste esquema conceituai, as relações econômico-ecológicas entre o campo e a cidade emergem como um temachave, o que é demonstrado pelo grande volume de produção acadêmica verificada tanto na geografia histórica como na história ambiental (ver, por exemplo, MUMFORD, 1956; CRONON, 1991; BRECHIN, 1999; GANDY, 2002; BRANNSTROM, 2005). As hinterlands constituíam reservas de recursos fundamentais ao adequado provimento dos centros urbanos pré-industriais, abastecendo-os com alimentos, água, combustível e materiais de construção por meio de circuitos comerciais de curta distância. A produção material dos espaços urbanos era um processo que envolvia, em si mesmo, a transformação de sistemas ecológicos inteiros, areia, argila, cal e madeira metabolizadas em construções e urbanidade concretas. Esta demanda exigia a drenagem de recursos ambientais das zonas rurais adjacentes. Além disto, as cidades, principalmente nos espaços coloniais, serviam amiúde como entreposto de captação e exportação das commodities agrícolas e/ou extrativistas.

Meu objetivo, neste artigo, é estudar, num nível ainda bastante preliminar e aproximativo, o comércio interno de madeiras de construção na Capitania do Rio de Janeiro, durante a segunda metade do século XVIII e primeiras décadas do XIX.Tentarei traçar um esboço das linhas gerais do sistema de produção-circulação madeireiro que conectava o Recôncavo da Guanabara e outras áreas rurais da Baixada Fluminense à "muy heróica e leal cidade de São Sebastião", dando ênfase a aspectos como as condições ecológicas de produção - combinação de elementos ambientais e técnicos pertinentes que preparam a cena para o comportamento econômico (13ARTH, 1981: 40) — o padrão de localização das áreas produtoras, as formas de comercialização e as relações sociais de trabalho e de troca. Antes disto, contudo, farei, à guisa de contextualização historiográfica, uma breve incursão pela literatura que versa sobre o comércio madeireiro na modernidade pré-industrial.

Entende-se por "madeira de construção" toda matéria-prima composta por fibra lenhosa que se destinasse à fabricação de bens de consumo duráveis, a saber, edificações, ferramentas de trabalho e utensílios mecânicos em geral. Ficavam excluídas, desta forma, as produções madeireiras que se destinassem à geração de energia (lenha e carvão). 


\section{Comércio e comerciantes de madeira na era moderna}

Como material de construção, a madeira teve sua demanda substancialmente aumentada com a aurora da modernidade, fenômeno estreitamente associado à revolução dos transportes marítimos, ocorrida na segunda metade do século XV. De acordo com S. W. Miller (2000:4), o navio de madeira foi a mais elevada expressão da cultura material do período moderno, bem como a grande ferramenta da expansão, dominação e comércio europeus. Embora as embarcações fabricadas com fibra lenhosa não fossem, em absoluto, uma novidade — babilônios, cretenses, egípcios, gregos e romanos, entre outros povos da antigüidade, já haviam depredado quase que sumariamente suas florestas para navegar mar afora - a evolução da técnica e da tecnologia náuticas, atuando num mecanismo de retroalimentação positivajunto à expansão qualitativa e quantitativa das trocas comerciais no âmbito de uma embrionária economia-mundo, modelou um cenário geopolítico no qual quem dominasse as florestas, certamente dominaria o mar. Nesse contexto, as potências européias buscavam garantir o seu suprimento de madeira para a construção de suas frotas mercantes e de guerra, desenhando legislações e políticas públicas para deter a depleção de seus estoques florestais, inclusive nos domínios de ultra-mar.

Dentre os sistemas de circulação madeireira mais importantes da modernidade destaca-se o do mar Báltico, não somente pelas inovações técnicas, mas igualmente pelo volume comercializado e pela relevância da movimentação dessa matéria-prima para a indústria de construção naval da Europa de noroeste. As coníferas do Báltico eram muito valorizadas, pois constituíam as únicas espécies de ocorrência regional, cujas propriedades físico-químicas satisfaziam a todos os requisitos (retilinidade cilíndrica, dureza, durabilidade e elasticidade) para a fabricação de uma peça essencial das embarcações - o mastro. Esse comércio madeireiro vinha, com efeito, desde o baixo medievo, quando o aquecimento climático permitiu a expansão das florestas sobre o norte da Alemanha e a península escandinava, ajudando a explicar o florescimento de um fantástico pólo de exploração naval que culminou com a chegada de drakkars vikings à costa americana; grandes rotas de intercâmbio foram estabelecidas entre os mercados de Novgorod e Smolensk e o Oriente Próximo. Posteriormente, a Liga Hanseática 
viria a ampliar essa já ampla rede de circuitos comerciais, herdada dos antigos povos germânicos, ligando, de modo generalizado, a produção madeireira das costas do Báltico às demandas de grande parte da Eurásia (MAURO, 1990:256-7; WILliAMS, 2003:196-201).

Outro centro de produção e distribuição de madeira muito importante da era moderna foi Veneza. Essa república independente, situada nas ilhas do mar Adriático, tornou-se uma grande potência marítimocomercial, ao longo dos séculos XV e XVI. Entre as mercadorias sobre cuja alienação se lucrava, estava a madeira. Veneza, de fato, tornou-se uma grande fornecedora desse produto para o mundo árabe. Estabeleceu-se um comércio florescente que estimulava a aquisição de mercadorias luxuosas no Oriente para a venda nos mercados europeus. Os lucros provenientes dessas transações fizeram deVeneza a cidade européia mais rica do período renascentista. Como mostrou Peter Burke, uma base econômica possível para a elite da sociedade veneziana composta por nobres ocupantes de importantes cargos políticos - tratava-se da comercialização da madeira extraída por arrendatários de suas terras localizadas no continente, principalmente nas áreas de Pádua, Treviso,Vicenza,Verona e Friuli (BURKE, 1991: 70-3) ${ }^{5}$.

Comojá foi dito, a madeira não era só o objeto do comércio, sendo também, em certo sentido, seu instrumento. Ainda no início do século XII, o doge de Veneza adotou uma política de fortalecimento da indústria de construção naval da república, composta por várias empresas privadas, reunindo-as e transformando-as num gigantesco estaleiro dirigido pelo Estado e que foi denominado Arsenal, palavra de origem árabe que significa "casa da construção" (PERLIN, 1992: 156). Com o decorrer do tempo, contudo, a frota mercante veneziana começou a enfrentar problemas com a gradativa redução de suas reservas florestais. Na segunda metade do século XVI, a madeira dobrou de preço; quase foi preciso interromper as atividades dos estaleiros, passando-se a comprar navios no exterior.

A importância dos agentes mercantis para a organização do comércio madeireiro aumenta significativamente com a chegada da segunda

O historiador inglês dá o exemplo de Antonio Priuli, nobre que chegou, inclusive, a ser doge deVeneza e comerciante que atuava no ramo madeireiro.Havia congêneres na elite de Amsterdã, com a diferença de que não eram nobres (p. 83). 
metade do século XVIII. De acordo com Michael Williams,"o comércio geral de madeira era, em grande medida, o resultado da ação de empreendedores individuais e raramente de governos". Em 1800, a praça de Londres contava com 75 mercadores de madeira, cujos depósitos se alinhavam ao longo do Tâmisa, entre Greenwich e Southwark, estendendo-se depois até as docas de Surrey. Liverpool possuía uma vintena deles, o mesmo podendo ser dito para todos os grandes portos de importação ingleses. Muitas firmas empregavam agentes locais devidamente treinados em idiomas estrangeiros, bem como inteirados da política local; o trabalho desses homens era, basicamente, observar e adiantar informações sobre as oscilações dos estoques e arranjar contratos com cortadores locais para embarcar a madeira. Apesar de raramente engajarem-se diretamente na esfera da produção, os mercadores e os agentes associados constituíam um link crucial no processo de exploração das florestas do mundo moderno (WILLIAMS, 2003: 300).

O Novo Mundo foi "anexado" ao sistema econômico mundial como uma gigantesca e aparentemente inesgotável fronteira de recursos, sendo a madeira um dos mais importantes. As técnicas de produção em massa ("lumberização"), que vinham sendo desenvolvidas na indústria madeireira do Báltico desde o medievo, puderam ser facilmente transplantadas para as brand new forests da América do Norte, associações vegetais biogeograficamente semelhantes às suas congêneres européias. A manufatura comercial de peças básicas de madeira - tábuas, pranchas, materiais de tanoaria, etc. - teve início no Maine e em New Hampshire, mas, no fim do período colonial, a atividade já se difundira por toda a Carolina do Norte. Em meados dos setecentos, as colônias americanas, principalmente a Nova Inglaterra, abasteciam as ilhas do Caribe com tábuas para construção. Em troca, os ianques - na sua maioria puritanos e quakers recebiam rum, que era trocado por escravos, em transações com negociantes europeus ou mesmo diretamente, através de expedições às costas do continente negro. Os comerciantes, então, voltavam para o Caribe e trocavam os escravos por açúcar, produto embarcado para a Inglaterra e negociado por bens manufaturados que, posteriormente, seriam vendidos na América; o lucro auferido retroalimentava o circuito (ROBERTSON, 1967: 84-5; LEÃO, 2000: 66-7; WILLIAMS, 2003: 197).

No Brasil, o tema do comércio madeireiro recebeu a atenção de alguns historiadores, embora apenas Larissa Brown (1986) - ainda que 
a madeira tenha sido apenas um dos itens de comércio por ela estudados - e Shawn W. Miller (2000) tenham recuado para além dos limites da segunda metade do século XIX. José Augusto Leandro (1999) teceu algumas considerações gerais sobre o Paraná provincial, Liliane Wentz (2004) estudou a fundo o norte do Rio Grande do Sul e Christian Brannstrom (2005), o Estado de São Paulo, estes dois últimos estudos englobando a primeira metade do século XX.

\section{O caso do Rio de Janeiro colonial tardio}

O estudo de Shawn W. Miller foi um louvável primeiro esforço de desbravamento e bem serviu, acredito, para abrir um novo e fascinante filão de investigação historiográfica. Como bem colocou Stuart B. Schwartz (2001: 553) em sua revisão da obra, Fruitless Trees constituirá, por muitos anos, um ponto de partida obrigatório para o estudo da indústria madeireira colonial brasileira. Entretanto, pela ousadia de seu escopo espacial e temporal - o que tem sido, até agora, uma constante na pesquisa e na escrita da história ambiental ${ }^{6}$ - o trabalho deixou, como infeliz efeito colateral, muitas lacunas.Tomo como meu objeto de estudo o Rio de Janeiro, capitania cuja atividade madeireira é, segundo o próprio Miller, a que menos conhecemos - em contraposição, por exemplo, a Alagoas, Paraíba, Pernambuco, Bahia e, até mesmo, ao Pará. Isto se deve, preponderantemente, à relativa falta de documentação concernente à madeira que afeta, de uma forma geral, a América portuguesa do sudeste e do sul, em contraposição aos domínios norteorientais (MILLER, 2000: 85-7)'.

\footnotetext{
" O eco-historiador parece comportar-se ainda como um pioneiro que sacrifica os pequenos recortes espaciais e temporais, que lhe permitiriam análise aprofundada, por vôs extensos, que o levam a reconhecer terreno e abrir caminho a outros pesquisadores" (SOFFIATI, 1997: 311).

'Este problema parece que se vai atenuando, conforme avançamos século XIX adentro, tanto no que concerne às diferenças regionais de disponibilidade de documentação quanto ao seu volume absoluto. B.J.Barickman,por exemplo, identificou mais de 250 requerimentos de licença para o corte de madeira relativos à região do litoral sul baiano, para o período 1825-1889, depositados no acervo do Arquivo Público do Estado da Bahia (cf. BARICKMAN, 2003: 360). Para o Rio de Janeiro, pude constatar a existência de uma quantidade razoável de documentos deste tipo, para o período pós-1830, no Arquivo Público do Estado do Rio de Janeiro.
} 
Mais do que como mercadoria de exportação, o aspecto de maior importância, em termos de desenvolvimento econômico, na "Idade da Madeira", era a quantidade e o preço da madeira de construção e da lenha, disponíveis no mercado interno, onde havia uma demanda largamente inelástica. Como material de construção, a madeira era um insumo indispensável a três grandes setores econômicos urbanos: a construção naval, a construção civil e o woodworking. Os estaleiros de construção naval eram as maiores e mais complexas empresas manufatureiras do Brasil colonial (CARDOSO, 1985: 67). A madeira constituía a principal e mais cara das matérias-primas utilizadas na construção naval (RODRIGUES, 2005: 88) ${ }^{8}$. Desde a segunda metade do século XVII, as ribeiras e os portos costeiros fluminenses faziam uso das florestas da hinterland para a fabricação de todo tipo de embarcações: pequenas barcas costeiras e de pesca, navios mercantes transatlânticos e mesmo alguns navios de guerra - embora tenha sido a Bahia, provavelmente, o mais importante centro brasileiro de indústria naval. A madeira também era importante para a construção das habitações, tanto no meio urbano quanto rural, importância que cresceu substancialmente depois de 1808, quando um boom na construção civil parece ter ocorrido nos arrabaldes da cidade (BROWN, 1992: 166). Dentre os artesãos urbanos, os trabalhadores da madeira faziam boa presença, como indica a existência de grande número de fabricantes de sapatos e marceneiros de várias especialidades (MILLER, 2000: 104).

Excetuando-se uma pequena área na região montanhosa de Itatiaia cujo clima frio e seco determina a existência de campos e cerrados - e das formações pioneiras de influência fluviomarinha, associadas ao grande delta do Paraíba do Sul, todo o território fluminense tinha como vegetação-matriz formações florestais ombrófilas e estacionais semideciduais, o que os ecólogos costumam chamar Mata Atlântica

O casco era a parte mais cara das embarcações, como Jaime Rodrigues (2005:91) pôde constatar por meio do inventário post-mortem de Elias Antonio Lopes, um influente traficante estabelecido no Rio de Janeiro nos primeiros anos do século XIX. Dentre os bens inventariados, há quatro navios, cujos cascos representavam metade ou mais do valor total das respectivas embarcações. Conforme argumenta o autor,"[e]mbora as outras partes fossem feitas de metal e o custo total incluísse itens como a artilharia e os escravos-marinheiros [...],só o volume de madeira empregado justificava a importância do casco na composição final de uma embarcação". 
lato sensu (mapa 1 - anexo I). "Florestas virgens, tão antigas quanto o mundo, ostentam sua majestade às portas da capital brasileira [...]", disse Saint-Hilaire (1932:18), em 1822.Tal cidade,"virtualmente cercada de florestas", como o Rio de Janeiro, tinha, portanto, todas as condições ecológicas para o desenvolvimento de uma densa rede de canais de comércio de madeira, ligando o core urbano às zonas rurais circunvizinhas (MORALES DE LOS RIOS FILHO, 2000: 278). O grosso da fibra lenhosa, no período em questão, era "drenado" das florestas costeiras da Baía da Ilha Grande e, principalmente, das médias e altas porções das grandes bacias hidrográficas da Baixada Fluminense, como as do Macacu,do São João, do Macaé e do Muriaé, onde ainda remanesciam, pouco modificados, vultosos estoques de Mata Atlântica montana e submontana (mapa 2 - anexo I). Por esses rios, assinalou José de Sousa Pizarro e Araújo, em 1794,"se conduzem do interior do sertão as madeiras precisas aos edifícios e ao fabrico das embarcações" (apud LAMEGO, 1964:193).

\section{A economia política da floresta}

Desde o começo do século XVII, as políticas de Portugal em relação às florestas brasileiras foram, invariavelmente, na direção da conservação das madeiras úteis ao Império, principalmente no que tange à construção naval. Deste momento em diante, observa-se uma trajetória contínua e gradativamente ascendente no que concerne à rigidez do controle exercido sobre os recursos florestais da colônia: de 1625, quando, ao que parece, se concedeu o monopólio da exploração madeireira à Companhia de Jesus (MA URO, 1989: 173), até a segunda metade da década de 1790, quando a regulação madeireiro-florestal atinge o seu ápice, com o monopólio de todas as matas à borda do mar e de todos os rios navegáveis - incluindo um plano organizacional complexo para a sua exploração?.

É importante salientar que, à exceção do pau-brasil, a exploração das madeiras "nobres" da floresta brasileira não se deu sob a forma da concessão de "exclusivos". A Coroa encarava a matéria como um assunto de segurança nacional, reservando para si a tarefa de gerenciar este gênero de recursos. Quase não há indícios de que empresas privadas tenham entrado no comércio de fibra lenhosa: a única que consegui identificar está no estudo de Jorge MiguelViana Pedreira (1995: 156), que cita a casa de comércio anglo-suíça Purry \& DeVisme. 
Este cerceamento político geral deve ser, contudo, matizado com algumas observações. Em primeiro lugar, a legislação das "madeiras de lei" parece ter sido de caráter regional, isto é, cada capitania tinha a sua lista particular de espécies, cuja exploração era interditada à iniciativa privada ${ }^{10}$. Em segundo lugar, a implementação e a administração deste sistema de regulação por parte da burocracia florestal foi um processo sempre permeado por ambigüidade, tensão e conflito, devido à oposição dos grandes proprietários e demais atores agrários (pequenos proprietários, arrendatários, posseiros, serradores, etc), que dependiam de um livre acesso aos recursos florestais. Quanto mais não fosse, a Coroa dependia do pleno funcionamento da economia colonial - da qual tirava grande proveito através de taxações - o que não ocorreria, caso se entravasse o acesso dos agentes privados às madeiras de que precisavam para produzir, inclusive na forma carbonizada. Consultado pelo príncipe regente D. João sobre a eficácia da lei de 5 de outubro de 1795, promulgada com o objetivo de regularizar a propriedade fundiária e demais assuntos concernentes à apropriação e ao uso dos recursos ambientais, nos limites das sesmarias - dentre eles, a conservação das madeiras-de-lei - o tenente-coronel Ambrósio de Sousa Coutinho assim se pronunciou:

Quanto ao cap. $1^{\circ}$, deve ter lemitação, p. q. prohibe os cortes dos mattos aonde há madeiras de L., e das rezervadas p." as construçoenz das Embarcaçoenz de V. Mag. , q. são - Tapinhoans, e Perobas —: deve-se advertir, q. em todo o território desta cap..$^{n a}$, não Há mattos desta natureza, como há na Europa, q. são plantados, e nos dillatados mattos deste paiz, os páos desta qualidade se achão distantes hunz dos outros,p.' cuja cauza não deve impedir as derrubadas $p .{ }^{\circ}$ augmento da Agricultura, e beneficio do Publico, $c$ dos Reaiz Dízimos. [...] [grifo meu]" .

Outro problema diz respeito à assunção de que a legislação florestal era, de fato, conhecida por toda ou grande parte da população rural,

\footnotetext{
Bastante indicativo desta desigualdade regional é o fato de que as Conservatórias de cortes de madeira, departamentos administrativos destinados a regular os cortes reais, foram estabelecidos, ao que parece, apenas em Alagoas, na Paraíba e em Ilhéus (cf. PRADO JÚNIOR, 1969: 323).
}

Arquivo Nacional do Rio de Janeiro, códice 807, v. 16, p. 188. 
suposição que me parece um tanto temerosa ${ }^{12}$. Há que se perguntar até que ponto as deliberações da Coroa chegavam aos ouvidos dos rurícolas coloniais, principalmente os mais pobres, assentados muitas vezes a dezenas de léguas de distância das vilas e dos centros administrativos. E, mesmo que as deliberações reais fossem de conhecimento público, o que nos garante que elas eram reconhecidas? Deve ter-se sempre em mente aquilo que Caio Prado Júnior (1969: 309) chamou de "solapamento da autoridade pública", isto é, uma distância generalizada entre o que era prescrito pela lei e a práxis cotidiana no espaço colonial; conforme argumentou Maria Regina Celestino de Almeida (2003:103), "as leis eram definidas nas relações cotidianas entre os agentes sociais e de acordo com os 'usos e costumes do lugar', expressão muito usada para justificar comportamentos considerados ilícitos".

Finalmente, deve-se coadunar a este cenário um elemento de incerteza quanto ao rigor com que devemos interpretar as evidências empíricas que se anunciam sob a rubrica das propaladas "madeiras de lei". Se a origem do termo realmente remonta aos reclamos de exclusividade da Coroa portuguesa, em meados do século XVII - e tudo leva a crer que sim - também é certo que a expressão foi mudando de significado ao longo do tempo, deslocando-se de sua acepção "jurídica" para uma outra, mais ampla, ligada à qualidade da madeira, o que é demonstrado pelo uso largamente difundido entre engenheiros florestais, agrônomos e fazendeiros nossos contemporâneos, os quais, a despeito disto, ignoram sua origem (BRANNSTROM, 2003: 176) ${ }^{13}$.

Da confluência destes fatores advinha uma organização bissegmentada da produção madeireira colonial: havia um setor formal e regulado pela Coroa e outro mais informal, baseado na livre-iniciativa.

\footnotetext{
Em relação à Inglaterra setecentista, E. P.Thompson (1987: 55) cita o exemplo do vigário de Winkfield, o Reverendo Will Waterson, que, quando chegou à sua nova paróquia, constatou que "as pessoas não sabiam a que titulo detinham suas propriedades, ou sob que aspectos estavam livres das ou sujeitas às leis florestais" [grifo no original].

${ }^{13}$ Talvez seja isto que devamos inferir do exame de muitos dos inventários madeireiros, principalmente da primeira metade do século XIX, que usam a denominação "madeiras de lei", mas que, na verdade, prestam-se tão-somente a listar espécies de alta qualidade. Parece ser este o caso, por exemplo, de PEREIRA, Adriano. "Relação de madeiras de lei" [Rio de Janeiro, s.d.] (Autógrafo). Coleção Freire Alemão. Biblioteca Nacional do Rio de Janeiro, Seção de Manuscritos, I-28, 10, 43.
} 
O primeiro setor seria diretamente organizado pela Coroa portuguesa de modo a suprir, principalmente, as necessidades de sua indústria naval. Esta organização se daria, basicamente, pelo mecanismo do monopólio, através do qual a metrópole garantia para a si o direito exclusivo de exploração de algumas espécies de árvores, as chamadas "madeiras de lei". S.W. Miller (2000:48-9) chama a atenção para a vacuidade da legislação madeireira, que não explicitava quais espécies eram, de fato, reservadas à Coroa. Para o referido autor, o fato de que nenhum colono tenha deixado registro de ignorância a respeito do status de uma árvore sugere que ou a lista era pequena o bastante para todos se lembrarem, ou muito grande, de modo que praticamente qualquer madeira útil era considerada propriedade real. Do meu ponto vista, nenhuma das duas opções. Para começo de conversa, ninguém, até hoje, encontrou um documento único e abrangente que relacionasse aquelas madeiras sobre as quais incidia a suposta lei — nem mesmo Miller. Fiéis à velha tradição colonial lusa da confusão e da verborragiajurídica, os reclamos estatais por madeira eram realizados à base de cartas régias e alvarás que, volta e meia, aportavam à mesa dos vice-reis, interditando o acesso dos particulares a esta ou àquela árvore. É altamente provável que relativamente poucas espécies da Mata Atlântica fluminense fossem sistematicamente empregadas na construção naval e, conseqüentemente, fossem objeto, senão de uma monopolização propriamente dita, pelo menos de uma atitude administrativa que engendrava um acesso preferencial da Coroa. Os documentos que analisei apontam para apenas três: o tapinhoã (Mezilaurus navalium),a peroba (Aspidosperma polyneuron) e o vinhático (Platymenia foliosa).

A unidade organizacional básica para a extração destas espécies era constituída pelas chamadas feitorias ou cortes reais ${ }^{15}$ que, segundo F.W.O. Morton (1978: 46) - que estudou a capitania baiana — podem

Adolfo Mondes de Los Rios Filho (21)00:45) fala de uma lei de 15 de outubro de 1827, que proibia o "corte das madeiras reservadas por lei, que eram a peroba, o tapinhoã e o pau-brasil".

$\mathrm{Na}$ documentação primária que analisei, o termo que aparece, de (ato, é "cortes reais" - do qual faz uso Morton (1978)."Feitorias"- termo utilizado por J. R. do Amaral Lapa (1968) - parece ser uma extrapolação da denominação dada aos entrepostos de escambo de pau-brasil estabelecidos por toda a costa brasileira desde os primórdios da colonização. 
ser vistos como "uma variante do familiar padrão de governo colonial brasileiro no qual a Coroa, em troca de lucros e recrutas, legitimava o controle e a exploração do campo pelas elites locais". No topo da estrutura burocrática estavam os inspetores e,mais tarde (a partir de 1797), os juizes conservadores das matas, autoridades com jurisdição sobre toda uma capitania, responsáveis pela supervisão de toda a cadeia de atividades madeireiras, desde a "colheita" até o transporte para os arsenais. Esta função foi preenchida, no Rio de Janeiro, por Diogo Toledo Lara e Ordonhes, nomeado em agosto de 1798, momento a partir do qual passou a acumular dois cargos públicos - ele já ocupava o posto de Intendente Geral do Ouro ${ }^{16}$. Aojulgar pela escassez de registros das suas atividades, o juiz parece não ter sido muito atuante na fiscalização das matas fluminenses. O único documento que pude encontrar a este respeito foi um relatório, feito por ele em parceria com o Intendente da Marinha, José Caetano de Lima, sobre os cortes reais instalados em Itaboraí e Santo Antônio de Sá, o qual foi expedido para Lisboa em julho de $1800^{17}$.

A dispersão das operações madeireiras da Coroa, ao longo do território florestado, levou à crescente nomeação de administradores para cortes específicos. Estes cargos eram, normalmente, assumidos por notáveis locais (geralmente, grandes senhores de terras) subordinados, em tese, ao inspetor, aojuiz conservador ou à própria Intendência da Marinha - o que fazia deles funcionários da Coroa.Todavia, o "funcionalismo da floresta" —adverte-nos E.P.Thompson (1987: 119) para o caso inglês - deve ser encarado "como um grupo específico de interesses e não como servidores leais de uma presença real". Corroborando esta hipótese, Morton (1978:44-5) demonstrou que os administradores dos cortes baianos eram, na prática, empresários locais, que constantemente burlavam os trâmites legais, reclamando salários de trabalhadores não-existentes, apropriando-se dos salários daqueles que de fato trabalhavam e/ou vendendo madeira real para consumidores privados. Acredito não haver razões para pensarmos de modo diferente no que concerne ao Rio de Janeiro do mesmo período. O administrador do corte de Papocaya.por exemplo, era o alferes Antônio de Amorim Lima,

Arquivo Nacional do Rio de Janeiro, códice 67, v. 23, f. 78.

${ }^{17}$ Idem, fs. 71-6. 
dono do maior engenho de açúcar de Guapimirim, onde estava localizada a capela-sede da paróquia, a de Nossa Senhora da Conceição. No referido relatório, redigido por Diogo Toledo e José Caetano de Lima, as duas autoridades assim comentam a postura do alferes:

A administração do [...] Corte, e da condução das Madeiras está confiado por V. Exa ao Alferes Antonio de Amorim Lima, Official que pela sua actividade, honra e zelo no desempenho da sua Comissão, tem merecido de V. Ex as mais honrozas expreçoens. Com tudo sendo como hé, muito mais fácil o transporte das ditas Madeiras por terra, do que as da Posse [no distrito vizinho de Itaboraí], elle encontra iguaes difficuldades em falta de Boys que as puxem por não se cumprirem, segundo diz elle, exactam ${ }^{\text {ie }}$ as respeitáveis ordens deV. $\operatorname{Ex}^{2}[\ldots]$ [grifo meu] ${ }^{18}$.

Aos administradores dos cortes era reservada a prerrogativa de reclamar bois e escravos dos fazendeiros para o transporte das madeiras reais, obrigação da qual todos, obviamente, procuravam livrar-se. Dispensar de bom grado os proprietários mais opulentos da cessão dos seus preciosos meios de produção em troca de favores políticos e econômicos devia ser um expediente amiúde usado pelos administradores, donde derivava, muitas vezes, a impossibilidade de alcançar os resultados cobrados pela Coroa. Parece ter sido este o caso do corte gerenciado por Amorim Lima, pois, conforme diziam os dois pareceristas,"os carros de bois"

[...] são bastantes para se fazer o transporte das Madeiras, sem detrimento dos Povos, logo que haja igualdade, $q$ supomos não ter havido na prestação deste Serviço. Para que elle seja regular quanto for possível nas actuaes circunstancias em que não há outros recursos, se faiz necessario que o Coronel de Milicias do Disctricto, e o dito Alferes Antonio de Amorim, formem cada hum seu Mappa de todos os Senhores de Engenho e Lavradores, que possuirem Bois de Carro, paraV. Ex ${ }^{a}$ mandar, a vista de ambos os Mappas, formar outro em que com attenção as possibilidades, e distancia em que vivessem os donos dos Bois, se distribua com igualdade por todos, o Real Serviço, ao qual ninguém se recuzará, conhecendo que nem o ódio, nem a amizade tem parte naquella destribuição [grifo $\mathrm{meu}{ }^{19}$.

${ }^{18}$ Idem.

I d e m. 
O segundo setor madeireira, até pelo fato de que poucas espécies de árvore eram úteis à construção naval - e, conseqüentemente, não incluídas na legislação das "madeiras de lei" - não estaria sujeito à regulamentação metropolitana. Embora seja verdade que o conhecimento da biota brasileira não mereceu muita atenção por parte das autoridades portuguesas - pelo menos durante os dois primeiros séculos e meio (DEAN, 1996: 101) - isto não significa que a floresta tenha permanecido à margem do escrutínio apropriador do homem comum. Assumindo-se que a dinâmica da cultura material "popular" implicaria na descoberta progressiva de usos cadavez mais complexos para as madeiras tropicais, podemos trabalhar com a hipótese de que havia muitos outros nichos de trabalho para além do abastecimento da indústria naval, estatal e privada. No âmbito da economia colonial brasileira - e, especialmente, a do período "tardio" — a indústria madeireira privada tenderia a ser, portanto, um dos componentes daquele "amplo mosaico de formas de produção não-capitalistas - que se utilizam do trabalho escravo, da peonagem, do camponês, etc. - garantidoras de uma oferta de alimentos e insumos básicos a baixos custos", ao qual se referiram João Fragoso e Manolo Florentino (2001: 55), sendo, na grande maioria das vezes, uma atividade-apêndice da agricultura itinerante, praticada por sitiantes, agregados ou pequenos proprietários escravistas.

De acordo com Pierre George (1963: 147), as economias agrícolas arcaicas caracterizavam-se pela estreita associação entre o cultivo propriamente dito e o que ele chama de "produções anexas" (a caça, a coleta, a extração de madeira, etc.). No que concerne ao caso particular do Brasil Colônia, podemos relacionar esta associação a uma característica estrutural da economia, qual seja, a sua precária divisão social do trabalho, advinda, basicamente, da utilização maciça de uma mão-de-obra escrava. O ponto ao qual desejo chegar, aqui, é a tendência à diversificação, muito mais do que à especialização, dos indivíduos e das famílias na assunção dos papéis econômicos. Este padrão de "infixidez ocupacional" foi taxativamente notado por Sérgio Buarque de Holanda (1995: 59):

Poucos indivíduos sabiam dedicar-se a vida inteira a um só mister sem se deixarem atrair por outro negócio aparentemente lucrativo. E ainda mais raros seriam os casos em que um mesmo ofício perdurava na mesma 
família por mais de uma geração, como acontecia normalmente em terras onde a estratificação social alcançara maior grau de estabilidade.

Um homem ou uma família (grupo doméstico) podia - e era bastante comum que o fizesse - combinar ocupações distintas dentro de um mesmo "setor" (produção, circulação ou distribuição) e até de setores distintos, em todos os níveis ou estratos da sociedade colonial. É isto o que mostram, por exemplo, os estudos sobre os mercadores: eles podiam atuar, simultaneamente, no intercâmbio transatlântico, na redistribuição interna e, ainda, investir na produção açucareira - não somente como financiadores, mas, propriamente, como senhores de engenho (ver, por exemplo, SMITH, 1975; FLORY, 1978; FRAGOSO, 1992; PEDREIRA, 1995). A formação escravista tendia a produzir, então, as mais variadas formas de combinação ocupacional, tipos socioeconômicos híbridos como o mercador-fazendeiro, o artesão-lojista, o marinheiro-comissário, o comerciante-rentier muitos outros. O agricultor-madeireiro não seria senão uma outra manifestação deste padrão geral, modelada sob circunstâncias sociais, econômicas, ecológicas e históricas particulares.

Não há boas razões para duvidar de que o ciclo dos "sítios volantes", conforme chamou Jacob Gorender (1980: 299), incluísse, antes da limpeza do terreno com fogo, uma fase de "apanha" das espécies fornecedoras de boas madeiras tanto mais sistemática quanto melhores fossem as condições logísticas (SCHMIDT, 1976: 45; DRUMMOND, 1997: 104). Obviamente que as espécies aproveitadas deviam ser poucas, se comparadas com a diversidade arbórea total de um trecho de Mata Atlântica - digamos, talvez, 10 ou 20 por cento ${ }^{20}$. Mas é preciso lembrar que nem toda a Mata Atlântica estava assentada sobre o precioso massapé e os solos precisavam ser adubados, o que significa dizer que era necessário queimar uma parte substancial de floresta. E, talvez mais importante do que isto, a terra precisava estar disponível para a plantação (isto é, desflorestada) rapidamente, o que um homem, sua família e uns poucos escravos (quando existissem) não poderiam realizar à base unicamente de machado.

De acordo com os estudos fitossociológicos, as florestas tropicais pluviais possuem entre 40 e 87 diferentes espécies arbóreas por hectare (cf. MORAN, 1994: 312). 
Por outro lado, pelo fato de haver árvores mais robustas (com troncos de maior diâmetro), que teimavam em remanescer mesmo após a queimada, era muito importante que se derrubassem antes que se tocasse o fogo, porque os lenhos secos eram consideravelmente mais difíceis de ser cortados $^{21}$. Segundo Pierre Deffontaines (1945: 564),"[a] floresta é verde e úmida demais para queimar em pé; não há incêndio de floresta sem uma derrubada prévia". As próprias modificações ecológicas estruturais impostas pelo corte seletivo à comunidade vegetal podem, como mostram os estudos experimentais de Andrew Holdsworth e Christopher Uhl (1997) e Monteiro e colaboradores (2004), aumentar o grau de combustibilidade da floresta, facilitando, assim, o trabalho do fogo no processo de expansão da terra arável. Em outras palavras - e usando os termos de Miller - o custo de oportunidade ${ }^{22}$ do arroteamento não-aproveitador de madeira era muito alto, isto é, a produção global (agricultura mais extrativismo) acabava ficando substancialmente mais cara, primeiro porque o terreno não era preparado adequadamente - o que influía na fertilidade do solo - e, segundo, porque se desperdiçava biomassa com potencial valor-de-troca. O padrão fitogeográfico da Mata Atlântica tendia a fazer com que, na maioria das vezes, só valesse a pena entrar na densa floresta primária para cortar algumas poucas árvores quandojá se fosse, no final das contas, derrubá-la por completo, de qualquer maneira, para plantar. Este tipo de racionalização ambiental pode ser exemplarmente auferido a partir de uma ordem expedida por D. Rodrigo de Sousa Coutinho, em 1797, para que fossem dispensados mil negros da Fazenda de Santa Cruz, a fim de serem empregados no corte de madeiras no vale do Paraíba do Sul:"Este trabalho", orienta o ministro ao Conde de Rezende,"deve executar-se, sem contudo ser dispendioso para a Fazenda Real: para este fim fará V.Ex.a estabelecer Roças ao longo do Rio, áproporçãoqueosCortesseforemextendendo; [... " ${ }^{23}$

Esta foi uma conclusão à qual chegou HermannVon Ihering (1908: 426 e segs.) por meio de estudos empíricos. Ansioso por responder à questão do tempo gasto pelos indígenas no processo de derrubada da mata, o antropólogo realizou experimentos com machados de pedra pertencentes ao acervo do Museu Paulista.

${ }^{22}$ Conceito associado à teoria dos custos, desenvolvida pelo economista Friedrich Von Wieser no começo do século XX, de acordo com a qual o custo de uma mercadoria é indicado pelas alternativas renunciadas para produzi-la (cf. SELDON \& PENNANCE, 1975: 125-6,485).

${ }_{23}$ Arquivo Nacional do Rio de Janeiro, códice 67, v. 22, f. 208. 


\section{Técnicas e tecnologia}

Pouco se sabe sobre os métodos de processamento utilizados na indústria madeireira colonial. Na falta de relatos contemporâneos e conterrâneos, costuma-se proceder através de extrapolações históricas ou geográficas. É o caso de S.W. Miller, quando este autor assume que a derrubada era feita em moldes bastante parecidos com os em voga na Europa do mesmo período: dois cortes em formato de cunha eram feitos simetricamente na base do tronco, sendo o primeiro e maior deles posicionado do lado para o qual se quisesse que a árvore tombasse. Enquanto os machadeiros aprofundavam os cortes, outros trabalhadores preparavam um catre de galhos sobre o qual o "gigante" pudesse cair sem ser danificado pelo impacto. Por vezes, quando possível, os ramos mais inconvenientes eram removidos antes da derrubada, com o objetivo de reduzir as chances de a árvore rachar, procedimento considerado supérfluo por alguns feitores mais experientes (MILLER, 2000:137).

A serragem era feita manualmente, utilizando-se dois trabalhadores e, aqui, devo confessar, também procedo por extrapolação, só que, neste caso, histórica. A tora, mais ou menos esquadrejada a machado (processo através do qual se obtinham pedaços de seis a 13 metros de comprimento), era colocada no chão, onde se posicionava um dos serradores; o outro se punha em cima do estrado. Ás vezes, em substituição ao buraco no solo, construía-se um estrado ou estaleiro pouco mais alto do que um homem, com os serradores ficando numa posição mais horizontal. O tipo de serra mais comum era aquela conhecida como "de estaleiro", com uma lâmina estreita na parte inferior e larga na superior (SOUZA, 1947: 10; MILLER, 2000: 137-8).

E muito provável que os equipamentos de serraria mecânica se tenham difundido, de modo substancial, apenas na segunda metade dos oitocentos ${ }^{24}$. De fato, encontram-se muito poucos indícios da existência dessas aparelhagens anteriores ao século XIX. A evidência mais remota de que tenho notícia está na escritura da propriedade comprada por João Rodrigues Pereira de Almeida (o futuro Barão de Ubá, homem de grande prestígio e fortuna), no ano de 1806, na freguesia de

\footnotetext{
${ }^{24}$ Warren Dean (1996: 180) afirma que eles se tornaram comuns era 1820, o que me parece um tanto precoce.
} 
Nossa Senhora da Conceição do Alferes, no distrito de Inhaúma; dentre as benfeitorias incluídas na transação (engenho, escravos, animais, etc), figurava uma serraria ${ }^{25}$. Essa fazenda abrigou o famoso naturalista francês Auguste de Saint-Hilaire, quando de suas andanças pelas terras fluminenses, em mais de uma oportunidade. Na penúltima delas, em março de 1818, o viajante relata que haviam sido feitos muitos melhoramentos nas instalações da propriedade desde sua última visita. Uma delas fora exatamente a construção de "uma máquina que movimentava os pilóes fazendo ao mesmo tempo mover uma serra e um moinho", executada pelo engenheiro mecânico François Ovide, membro da mesma missão artístico-cultural que trouxeraJean Baptiste Debret, em 1816 (SAINT-HILAIRE, 1974:122). Deixado no ócio pelo governo português quase desde a sua chegada, Ovide passara a se dedicar, então, à instalação de engenhos, rodas d'água e máquinas em geral por todo o território da capitania (MORALES DE LOS RIOS FILHO, 2000: 296), donde é provável que se tenha dado, a partir de seus esforços, um primeiro e importante impulso ao progresso tecnológico da indústria madeireira fluminense.

A extração das árvores era realizada nos vales dos rios, abaixo das corredeiras. Na região da Mata Atlântica fluminense, esta era uma área muito limitada, devido à barreira da escarpa costeira. Grande parte das madeiras nobres eram mais pesadas que a água e tinham, então, que ser transportadas em balsas, junto com madeiras mais leves, para trazê-las ao porto ou local de benefíciamento, donde que descê-las por cascatas ou corredeiras era uma tarefa muito mais complicada (DEAN, 1996: 180). Apenas umas poucas espécies tinham valor de mercado e nunca eram encontradas em bosques densos, mas sempre espalhadas na floresta primária remanescente; estima-se, por exemplo, que fossem encontradas apenas três ou quatro exemplares de peroba (Aspidosperma ramiflorum) em um alqueire de mata (DEFFONTAINES, 1945: 567). Todas estas circunstâncias elevavam sobremaneira os custos de produção, fazendo com que o investimento na atividade madeireira fosse rentável somente para aqueles rurícolas assentados bastante próximos da franja florestal. Em

Este documento fiz parte do conjunto documental Escrituras públicas de compra e venda, pertencente ao acervo do Arquivo Nacional do Rio de Janeiro e examinado porJoão Fragoso e Manolo Florentino (2001: 159-61). 
meados dos setecentos, passada a avalanche devastadora do primeiro ciclo do açúcar, o avanço da fronteira agrícolajá tinha confinado a mataria mais densa às fraldas da Serra dos Órgãos (AMADOR, 1997: 270, 275).

\section{Organização socioeconômica}

Enquanto atividade destinada à manutenção mais elementar do produtor e sua comunidade - através da fabricação de mourões de cerca, caixotes, cabos de enxada e machado, gamelas, cangas, mobília e muitos outros utensílios necessários à vida no campo - a indústria da madeira estava presente, em maior ou menor nível de sofisticação, em todos os tipos de unidades agrícolas. No caso das grandes propriedades açucareiras, o recurso à fibra lenhosa era essencial ao pleno funcionamento do complexo agroindustrial; os engenhos possuíam serraria, marcenaria e carpintaria (DIEGUES JÚNIOR, 1960: 116). Estudando minuciosamente o caso do engenho do Camorim (situado no maciço da Pedra Branca, zona oeste do atual município do Rio de Janeiro), Carlos Engemann e seus colaboradores (2005: 124-36) mostraram que as cinco principais demandas de produtos florestais eram: (a) instalação de cercas, (b) reformas dos madeiramentos das construções, (c) fabrico e manutenção dos carros de bois, (d) construção de caixas para embalagem do açúcar e (e) fornecimento de lenha para as caldeiras. Todas elas destinavam-se ao consumo interno da unidade produtiva, com a possível exceção das caixas - ou "caixões", como eram comumente $\operatorname{chamados}^{26}$. O valor dado às madeiras supracitadas, de importância fundamental para o bom funcionamento dos engenhos, justifica que houvesse preocupação com a manutenção de seu estoque nas matas da propriedade. Práticas predatórias que tornassem estes indivíduos ainda mais afastados e escassos eram combatidas pelos proprietários dos engenhos e rejeitadas pelos carpinteiros encarregados de produzir os equipamentos necessários à indústria do açúcar (C A S T R O, 2002: 101). É provável que a grande demanda interna não permitisse que os engenhos produzissem madeiras para fora, sob pena de esgotamento destes escas-

\footnotetext{
${ }^{26}$ O distrito de Guaratiba, por exemplo, parece ter-se especializado numa indústria comercial de caixões de açúcar: no ano 1778, serraram-se quase 900 destas embalagens de madeira (cf. LAVRADIO, 1946 [1779]: 329).
} 
sos recursos; com efeito, é muito mais plausível que eles constituíssem, pelo contrário, um substancial mercado consumidor ${ }^{27}$.

No caso das pequenas unidades agrícolas, geralmente produtoras de gêneros alimentícios, a indústria madeireira estaria presente, segundo Miller (2000: 128), como um "outro ramo de atividade econômica da grande população de subsistência". Neste contexto, em razão da "insuficiente quantidade de moeda e excedentes para a aquisição de bens produzidos por terceiros" (MILLER, 2000:128), a indústria da madeira convertia-se numa atividade de mercado, desenvolvendo-se de modo paralelo às demais atividades comerciais e de subsistência. Em outro trabalho, demonstrei, através de indicadores quantitativos (participação das classes agrárias no número de madeireiros, tanto total como interno à classe, e as produções médias), corroborados por indícios textuais - como o da troca de madeira por mantimentos nas tavernas - que os atores responsáveis pela produção madeireira, na Santo Antônio de Sá de fins do sécu1o XVIII, eram os pequenos produtores de gêneros alimentícios ("lavradores" e "fabricantes de farinha") (CABRAL, 2004: 134-6). Sobre estes indícios, erigi, então, a hipótese de que a indústria madeireira comercial podia ser explicada como uma estratégia dos produtores agrícolas de subsistência em face dos constrangimentos impostos pela estrutura socioespacial à sua sobrevivência e reprodução:

No Brasil colonial, salvo raras exceções, o pequeno produtor rural não pôde estabelecer um vínculo de cooperação com o ambiente. Não havia tempo para isso, ele não podia perder sequer uma única oportunidade de extrair da natureza qualquer mercadoria que lhe proporcionasse bons rendimentos no momento da troca; afinal de contas, nunca se sabia quando o senhor de engenho ao lado iria expulsá-lo de suas terras e deixá-lo à deriva pelo sertão. Em outras palavras, a extrema instabilidade e precariedade de seu relacionamento com a terra parece ter produzido um vínculo de saque entre o peque-

Sugestivamente, o reconhecimento da economia madeireira como uma criadora de laços de solidariedade econômica interna ao espaço colonial aparece nos mesmos autores que difundiram e consolidaram a idéia dos engenhos como unidades autárquicas. Celso Furtado (1976:44), por exemplo, o co-fundador da velha escola dependentista, escreveu que "o engenho realizava um certo monte de gastos monetários, principalmente na compra de gado (para tração) e de lenha (para as fornalhas). Essas compras constituíam o principal vínculo entre a economia açucareira e os demais núcleos de povoamento existentes no país". 
no produtor de subsistência e o ambiente, o fenômeno da indústria madeireira comercial representando apenas um caso particular desta relação geral (CABRAL, 2004: 138, grifo no original).

Em todas as áreas do território fluminense próximas às fraldas e aos contrafortes da Serra do Mar, a densa floresta ombrófila e o relevo acidentado não permitiram que fosse a pecuária a atividade responsável pelo desbravamento dos sertões no processo de avanço da fronteira agrária, como ocorreu, muito freqüentemente, no processo de colonização de outras áreas do Brasil colonial. Este papel teve que ser desempenhado pelo que convencionamos denominar "sítios agro-madeireiros", isto é, pequenos produtores agrícolas que praticavam o extrativismo e o beneficiamento primário da madeira tropical como atividade acessória, na esteira do processo de arroteamento. Em geral, estes atores agrários, no intuito de se resguardarem contra as adversidades de um cenário econômico em constante oscilação, principalmente quando se pensa em situações de fronteira aberta, buscavam uma multiplicidade de fontes de renda. Ao desenhar este quadro, parece-me interessante tomar como referência o modelo empírico apresentado por Gabriel Medina. Estudando, através de métodos de história oral, uma pequena comunidade (Quiandeua) localizada às margens do rio Capim, no nordeste paraense, o autor desenha um quadro no qual a indústria madeireira é realizada por famílias pobres, vindas das terras baixas, e que encontram no extrativismo um meio eficaz de adquirir itens que elas não podiam produzir (sabão, tecidos, terçados, machados, enxadas, azeite, etc.), fornecidos pela Belém em expansão das primeiras décadas do século XX. Segundo Medina (2004: 314), estes indivíduos viam a floresta como uma "herança com valor de troca de uso não conflituoso":

Herança porque utilizada ao longo do tempo conforme as necessidades e oportunidades de modo a garantir a manutenção e desenvolvimento do grupo que se estabelecia. Em comparação com outros produtos da mata, a madeira foi o único que sempre apresentou valor de troca relativamente alto. Além disso, não cabe [...] a idéia de conflito de uso entre a extração madeireira e a coleta de outros produtos para o uso local ou para venda. Representada desta forma, a venda da madeira aparece como uma possibilidade estratégica de melhoria das condições de vida das famílias da comunidade [grifos no original]. 
Mas, se a madeira era um trunfo freqüentemente utilizado, a lavoura dificilmente poderia ser deixada completamente de lado. Sobressai, por conseguinte, a questão da relação que as produções agrícola e extrativista travavam no interior da dinâmica econômica das unidades domiciliares. O problema aqui não é, vale lembrar, o do contato e da difusão de uma cultura "ocidental", transformando um padrão "tradicional" de uso dos recursosflorestais, processo estudado in situ por muitos antropólogos econômicos nos espaços de fronteira étnica, mas sim o modo como o "status" (num eixo qualitativo - autoconsumo ou mercado) e o "peso" (num eixo quantitativo) das duas atividades mudavam relativamente na estratégia reprodutiva das famílias. O que deve ter modelado esta diferenciação foi o entrejogo de fatores objetivos - principalmente a condição fundiária do fogo (se em terras próprias ou de senhores) e sua distância em relação à mata - e o desenvolvimento de alguns padrões transacionais entre o "madeireiro" (representado aqui pelo chefe da família ou unidade produtivo-domiciliar) e o ambiente florestal - relações de prestação e contraprestação do tipo que ocorre quando o ator investe numa produção extrativista e é ou não recompensado com ganhos monetários - e também entre aquele e os demais atores que atuavam no mesmo cenário relações com o senhor das terras, no caso dos agregados, relações com as autoridades coloniais, no caso de requisitar licença oficial para o corte, etc. Este sistema de variáveis devia produzir um espectro de formas, cujos extremos eram representados, num pólo, pelo pequeno lavrador que praticava o extrativismo para suprir necessidades domésticas e, noutro pólo, pelo extrator licenciado que praticava sua indústria como atividade principal - ou pelo menos em pé de igualdade com a agricultura - muitas vezes promovendo a extração em terrenos alheios.

Para ter valor de mercado, a terra precisava ser desmatada e seu valor era dado,justamente, pelo trabalho que nela se aplicava, um trabalho caro para a época (CALDEIRA, 1999:71). Por isto, na maioria das vezes, no processo de abertura das fazendas, o trabalho de "limpeza" da mata era confiado a trabalhadores livres, de alguma forma ligados à extensa família patriarcal do senhor das terras (os agregados), em troca do direito de usar temporariamente as áreas desmatadas para a agricultura e/ou comercialização das madeiras retiráveis ${ }^{28}$. Como entre proprietá-

\footnotetext{
2 Isto significava, em última instância, pagar com árvores ao invés de escravos o arroteamentojá que estes eram muitos mais valiosos, como mercadoria-moeda,do que
} 
rios e agregados não se formalizava nenhum tipo de contrato escrito e legalizado, mas apenas uma convenção verbal, que o proprietário podia romper ao seu arbítrio a qualquer momento, os que se estabeleciam em terreno alheio, via de regra, consideravam mais seguro fazer investimentos de curto prazo, como lavouras, cuja colheita pudesse ser feita em poucos meses - como o milho e o feijão - e, é claro, o extrativismo madeireira.

Parece ser razoável pensar que, à medida que se avançava século XIX adentro, taxas cada vez maiores de desflorestamento conduzissem a uma elevação dos preços das madeiras, estimulando o engajamento na atividade extrativa em detrimento do cultivo - que poderia, então, chegar ao nível da mera subsistência. O autor anônimo da Discripçao do que contém o Districto daVilla de Santo Antonio de Sá de Macacú assim descreve, em 1797, a atração que o extrativismo madeireira exercia sobre os agricultores:

[...] he o da faitura das Madeiras hum dos negócios em qe muitos [lavradores] se empregão com o qual se faz mais vantajoza a sua negociação, pela utilidade qe recebem da extração dellas, qe he grande, e geral [...]. Ella he de tal interece qe sendo Laborioza, e pesada a sua faitura, e Condução pa os Portos de Embarque, nem por isso deixão de continuar com as fabricar $[\ldots]^{29}$.

aquelas - afinal de contas, os negros podiam ser feridos ou mortos por picadas de insetos ou cobras, galhos ou árvores que tombavam, fogos descontrolados ou quaisquer outros tipos de acidentes (DRUMMOND, 1997: 1(13-4).

29 "Discripção do que contém o Districto da Villa de Santo Antônio de Sá de Macacú, a qual foi mandada tirar pelo Ilmo e Exmo Sor Conde Vice Rey, em 7 de Abril de 1797". Arquivo Histórico Ultramarino de Lisboa, Avulsos, Caixa 165, n 62, s/p, cap. IX. O manuscrito se encontra dividido em duas partes: a primeira se constitui numa descrição qualitativa (textual) do distrito, abordando diversos temas inerentes ao sítio (paisagem física) e à vida social, econômica e cultural; a segunda é composta pelos "mappas", isto é, a lista nominativa de habitantes. A descrição textual nãopaginada se distribui por 19 capítulos, sendo que se encontram completamente ausentes do nosso material os capítulos dois e quatro, enquanto os de número um, três e cinco estão incompletos. Uma cópia deste documento nos foi muito gentilmente cedida pelo professor Maurício de Almeida Abreu, sem a qual eu não poderia ter realizado a minha monografia de graduação, intitulada "O açúcar, a farinha e a floresta: sistemas agrários e indústria madeireira em Santo Antônio de Sá (RJ), final do século XVIII", orientada pelo referido professor e submetida ao Departamento de Geografia da Universidade Federal do Rio de Janeiro no começo de 2004. 
Em fins da década de 1810 , a visitar o vale do rio São João, Auguste de Saint-Hilaire (1974: 179) relatou observações que também poderiam apontar nessa direção:

Grandes florestas virgens margeiam o rio que tem cerca de 18 léguas de curso; os proprietários ribeirinhos derrubam e serram as árvores melhores e vendem as tábuas a negociantes de S.João, que as expedem para o Rio de Janeiro. [...]

Como os colonos empregam ordinariamente seus escravos no trabalho da derrubada, não cultivam senão o necessário ao consumo de suasfamílias.

De fato, há indícios que permitem pensar que, eventualmente, o extrativismo madeireiro pudesse ascender ao primeiro plano da estratégia econômica camponesa. Passando em revista as freguesias do distrito de Cabo Frio, Manuel Aires de Casal relatou, em 1817, que os habitantes de Macaé "recolhem milho, arroz, feijão, farinha, algum açúcar; tiram madeira, sua principal riqueza". Na freguesia de São João, o panorama era o mesmo:"Afora a madeira, por hora a riqueza principal de seus habitadores, exporta-se variedade de comestíveis" (CASAL, 1943: 32).

É muito provável que estes produtores tenham utilizado, além de uma pequena escravaria, a mão-de-obra nativa, em regimes variados de trabalho assalariado. Para que isto se tornasse possível, desempenharam papel fundamental as aldeias missionárias, as quais proporcionaram um espaço importante para a "re-configuração" das identidades indígenas ao longo de todo o período colonial. Segundo Maria Regina Celestino de Almeida (2003: 202), o "corte de madeiras, primeiro serviço prestado pelos índios aos europeus, iria se manter até o século XIX, tanto no setor público quando particular". "Não é de admirar", argumenta Warren Dean (1996:180-1),

[...] que grupos tribais que haviam sido assentados em aldeias fossem capazes de se integrar no comércio como lenhadores. Inteiramente familiarizados com o terreno, eram especializados no reconhecimento das espécies de árvore e estavam dispostos a trabalhar em tarefas ocasionais e sem supervisão.Tornavam-se também serradores; na verdade, especializavam-se nesta arte. 
Neste sentido, não surpreende o fato de que se tenham acirrado os conflitos entre os setores madeireiros estatal e privado pela utilização da força de trabalho barata e qualificada dos índios, após a expulsão dos jesuítas, em 1759 (MILLER, 2000:109-10). Há, inclusive, relatos de práticas de extorsão do trabalho indígena, incluindo-se aí a exploração de madeira. Em 1779, o capitão-mor João Baptista da Costa encaminhou à rainha Dona Maria I um detalhado relatório, contendo graves denúncias contra o desembargador Manoel Francisco daVeiga e o diretor da aldeia de São José Del Rei (localizada entre os atuais municípios de Cachoeiras de Macacu e Nova Friburgo), Feliciano Joaquim de Souza. No referido documento, eles eram acusados de obrigar os aldeados a roubar madeira em matas alheias. Segundo o denunciante, cada índio produzia dez feixes de lenha por dia, os quais eram vendidos na cidade, ficando o dinheiro com o diretor do aldeamento (CAVALCANTI, 2004:113).

\section{A circulação}

No Rio de Janeiro, como em todas as demais capitanias da colônia, em decorrência da já vista organização geral da produção, conformavam-se duas grandes esferas de circulação das madeiras, as quais podem ser chamadas de "estatal" e "privada". A primeira, como decorrência do mecanismo institucional monopolístico das "madeiras-de-lei", baseava-se na singela prerrogativa da qual estavam investidos os agentes da administração colonial que lhes permitia, a qualquer momento, o "confisco remunerado" de peças produzidas por particulares. Nas suas Memórias sobre os cortes das madeiras da Capitania do Rio de Janeiro, escritas no ano de 1800, o sargento-mor José Correa de Bulhões conta serem as madeiras

[...] compradas por hum preço sempre mais inferior ao seu valor, e que quem as vende deve fazer quer queira, quer não huma viagem a Capital para receber o producto das madeiras, e para isto mesmo deve passar pelos incommodos de esperar certos despachos, para receber o importe, o que tudo contribue para maior prejuízo do vendedor, que pelo commum he sempre hum dos habitantes dos Districtos mais distantes da Cidade, o qual se remetesse as mesmas madeiras aos seus correspondentes, receberia o seu 
importe muitas vezes sem o incommodo de huma viagem nem sair das suas fabricas ${ }^{30}$.

Em linhas bem gerais, o processo tinha início com a detecção de uma demanda nos arsenais metropolitanos. Despachava-se, então, uma solicitação para o vice-reinado. Os códices 67 e 68 do Arquivo Nacional do Rio de Janeiro contêm inúmeras correspondências que se encaixam nesta descrição. Estas solicitações de remessa de madeiras podiam vir com menores ou maiores especificações. Em março de 1797, por exemplo, D. Rodrigo de Souza Coutinho encaminhou o seguinte requerimento, curto e grosso:

Para o Arsenal da Marinha desta Corte se faz preciza hua grande quantidade de Madeira de Tapinhoão, Paroba e Vinhático: E he Sua Majestade servida, que V.Ex.a remeta por todos os Navios, que sahirem desse Porto, a maior porção, que poder, das ditas Madeiras ${ }^{31}$.

De modo semelhante, em 1802, José Caetano de Lima, o primeiro intendente naval da capitania e que havia sido nomeado quatro anos antes, recebeu ordens para mandar 150 pranchas de peroba e vinhático para Lisboa (BROWN, 1992:167). Noutras ocasiões, contudo, os requerimentos eram muito mais detalhados quanto às madeiras a serem remetidas, contendo especificações relativas aos tipos de peças e às suas dimensões. Estas demandas eram escritas pelos próprios mestres de ribeira ou por auxiliares seus. Em junho de 1805, foi enviada ao Rio de Janeiro a seguinte lista, preparada porJoão Filippe da Fonseca, oficial da Secretaria de Estado:

Sintas direitas de 11 a 12 polgadas de grosso, e de largo 16 a 18 ditas com o maior comprimento que poderem ter.

Ditas de volta para a Proa e amura que tragão mais grossura para os empenos.

Ditas para dormentes de 9 a 10 polgadas de grosso e largura e comprimento o maior que poder ter.

Biblioteca Nacional do Rio de Janeiro, Seção de Manuscritos, I-11,01,019, pp. 6-7. Arquivo Nacional do Rio de Janeiro, códice 67, v. 22, f. 72. 
Ditos de volta para a Proa e Amura que tragão mais grossura para os empenos.

Ditos para Trincanizes de 10 a 12 polgadas de grosso, e de largo $18 \mathrm{com}$ o maior comprimento que poderem ter.

Ditos de volta para a proa e amura com as mesmas dimençoens acima.

Taboado para o fundo e couceiras de $4 / 2$ a seis polgadas de grosso, comprimento e largura o mais que poderem ter.

Paos de volta para cachimbos e costado, e couceiras na proa e na amura.

Curvas para o alto e abertonas de 8 a 11 polgadas de grosso a maior quantidade que poder ser.

Paos para Paos de 14 por 16 polgadas de grosso, e de comprido 60 a 4 pez.

Paos para cavernas de Pródigos e $1^{\circ}$ e $2^{\circ}$ braços ditos de 13 a 14 polgadas de grosso.

Ditos que possão servir de Baçardas para a Proa e Popa de 14 a 15 polgadas de grosso.

Paos para Rodas de Proa e Capetos,e Madres de Boque de 15 polgadas de grosso.

E alguns para colunas e paos e encher a Proa.

Taboado de Tapinhuam para forro.

Dito de fundo de Barca de 2 polgadas de grosso.

$$
[\ldots]^{32} \text {. }
$$

Ao receber pedidos como este, o vice-rei acionava a administração do Arsenal de Marinha do Rio de Janeiro, inaugurado em 1765, dois anos depois de o Conde da Cunha mandar construir a "ribeira" no terreno cedido pelos beneditinos, ao pé do seu Mosteiro (GREENHALGH, 1951: 17-27). A madeira necessária ao empreendimento foi, em parte, doada pelos anacoretas de São Bento e, em parte, encomendada às "pessoas que assistem no termo de Macacu, e costumam fazer negócio em madeiras", segundo relatou o Conde da Cunha, em dezembro de 1963. Todavia, com o andar da obra, viu-se que era necessário utilizar troncos de grande comprimento, exigência que os fornecedores privados se mostraram incapazes de atender, obrigando o vice-rei a enviar carpinteiros e oficiais militares para extraírem das matas do vale do Macacu a madeira requisitada (CAVALCANTI, 2004: 84).

Anexo de carta do Visconde de Anadia aoVice-Rei D. Fernando José de Portugal. ANRJ, códice 67, v. 31, fs. 40-1. 
Além, evidentemente, de construir e reparar navios, o recém-levantado Arsenal tinha como responsabilidade a captação e o armazenamento das madeiras provenientes dos cortes reais e que seriam, posteriormente, embarcadas para Lisboa. Contudo, no estado ocioso em que se manteve a ribeira em todo o vice-reinado e mesmo durante a estada da Corte joanina - as calafetagens não eram tão freqüentes e a nau São Sebastião foi a única embarcação importante construída (GREENHALGH, 1951: 112) - o que deveria ser uma função adicional, acessória, acabou por se tornar o leitmotiv do complexo.Juan Francisco de Aguirre assim descreveu o trapiche, em 1782: "Trata-se de uma construção pequena, que dispõe somente de armazéns e galpões" (FRANÇA, 1999: 151). Os oficiais incumbidos de zelar pelo estoque de madeira, renovando-o quando necessário, eram o Mestre e o Contramestre da ribeira, que lideravam e supervisionavam as expedições aos distantes distritos florestais na periferia da cidade, onde faziam conduzir as madeiras dos particulares que se achavam "feitas dentro dos mattos, ou nos pórtos prontas para embarcarem ${ }^{13}$.

$\mathrm{Na}$ esfera privada, na qual não se fazia presente a intervenção da Coroa, a circulação das madeiras era condicionada pela estrutura geral da economia colonial tardia. Nu m tal cenário de precária divisão social do trabalho, no qual a penúria da circulação monetária era inevitável, abria-se espaço para o controle do crédito pelos poucos agentes com acesso ao metal — os comerciantes. E "sabe-se que, por si mesma, uma economia marcada pela hegemonia do capital mercantil esteriliza enorme parcela do excedente produzido" (FRAGOSO e FLORENTINO, 2001: 228). E o que, em termos ecológicos, significa a esterilização do excedente, senão um fluxo unilateral de matéria (elementos químicos) e energia para fora dos ecossistemas domesticados, um déficit permanente, que impõe uma renovação dos estoques de nutrientes baseada num avanço sem-fim sobre novas matas? "Na medida em que as energias gerais do país são destinadas à ampliação do poder do comerciante" - escrevia Henry Carey sobre os Estados Unidos da América, em 1858 - "não é surpresa que o seu povo seja visto em toda parte como estando empregado em 'roubar a terra do seu estoque de capital'" (apud FOSTER, 2005:216). A moderna apropriação da Mata Atlântica deu-se,

Biblioteca Nacional do Rio de Janeiro, Seção de Manuscritos, 1-11,01,019, pp. 6-7. 
assim, no bojo do processo de construção de uma "forma peculiar, extrativa, de capitalismo, na qual o estoque de capital é totalmente in natura, preexistente à ocupação neo-européia, e rapidamente dissipado" (DEAN, 1996: 94).

O comércio madeireiro privado representava a modalidade mais incisiva e dilacerante de espoliação da terra. Como enfatizou Karl Polanyi (2000: 94), "[t]erra é apenas outro nome para a natureza, que não é produzida pelo homem". Se uma lavoura de cana, mandioca ou feijão permitia um mínimo de reutilização dos seus fatores de produção ambientais (solo e biomassa carbonizada), a exploração de madeira nem isto; uma vez alterado o regime natural de sucessão ecológica, a mata em regeneração não conteria as mesmas espécies maduras durante um século ou mais (DEAN, 1996: 180). De fato, a apanha de algumas poucas árvores preciosas no meio da selva densa era algo bastante diferente de uma autêntica silvicultura ${ }^{34}$, um ramo do saber que já se vinha desenvolvendo, de forma mais sistemática, noVelho Continente, desde a publicação do famoso livro de John Evelyn, Sylva, or a Discourse of Forest-Trees and the Propagation ofTimber in his Majesty's Dominions, em 1664. Uma economia cuja reprodução tinha como mecanismo básico a incorporação contínua e não reaproveitável de recursos ambientais, cuja disponibilidade era ditada, basicamente, por um processo de longuíssima duração - a sucessão ecológica que conforma as comunidades vegetais - e que, ainda por cima, esterilizava enorme parte da riqueza produzida, deve ser caracterizada como uma verdadeira Raubwirtschaft- "economia de rapina" contemporâneo, totalmente insustentável.

Para a realização do valor de troca da biomassa tomada à floresta, não bastava o gingar dos machados. Como preconizou Karl Kautsky (1980: 200-1) em sua teoria do trabalho acessório, a indústria rural (a escultura em madeira, a fabricação de ardósia, lápis, cestos, a serralheria, etc), como produção de mercadorias,"só pode desenvolver-se em associação a um capitalista, um comerciante ou um depositário capaz

"[...] o corte de árvores em florestas naturais é extração, mas o corte de árvores plantadas para esse fim é uma forma especial de agricultura, a silvicultura" (DRUMMOND), 2002: 8, grifo meu).

Este conceito foi originalmente cunhado por Ernst Friedrich (1904). Mais tarde, ele viria a ser amplamente adotado por outros geógrafos, inclusive Carl Sauer, 
de estabelecer comunicações com um mercado distante, ao qual o camponês isolado não consegue chegar diretamente". Neste sentido, os comerciantes jogavam, nas economias agrárias arcaicas, um papel fundamental no processo de espoliação econômico-ecológica do campo em face das demandas urbanas.

O comércio de madeiras estruturava-se de modo hierárquico, como, aliás, não poderia deixar de ser (BRAUDEL, 1970:340). Na bacia do rio Macacu (porção nordeste do Recôncavo da Guanabara), por exemplo, a produção era escoada através dos pequenos portos fluviais ${ }^{36}$, onde as madeiras eram vendidas a pequenos mercadores ou, como eram conhecidos à época, atravessadores ${ }^{37}$. Em 1810, John Luccock (1951: 222) descreveu uma área no médio vale do Macacu como sendo composta por pequenos lavradores que "[...] acrescentam aos seus parcos meios de subsistência e divertimento, cortando madeira na mata, lavrando-a e serrando-a em tábuas, vendendo no porto de Pirassununga". Como os portos eram privados - em razão de as terras doadas como sesmarias incluírem as águas litorâneas (FRIDMAN, 1999:84-5) - os próprios donos das docas fluviais faziam freqüentemente o papel de negociantes, comprando a madeira dos cortadores locais e vendendo-as na cidade. Muitas vezes havia, ainda, em razão da necessidade de vencer grandes distâncias, a atuação de um segundo intermediário, ao qual cabia o transporte das madeiras dos portos fluviais aos portos marítimos. Cabo Frio, por exemplo, em 1778, contabilizava seis "lanchas de tabuado", as quais, somente na falta desta mercadoria, conduziam mantimentos (LAVRAdio, 1946[1779]: 310). Com efeito, estes conjuntos de negócios deram origem ou permitiram a sobrevivência de alguns povoados e cidades de "boca de sertão", na medida em que serviram, por muito tempo, como o centro de comercialização inicial dos produtos extrativos que fluíam para o Rio de Janeiro. Em 1818, Auguste de Saint-Hilaire (1974: 179) observou que a vila de São João da Barra era "um entreposto comercial de madeira bem considerável". De fato, isto é confirmado por Larissa Brown; a autora assinala que, entre 1799 e 1822, o porto supracitado constituía uma das fontes mais importantes de abastecimento madei-

\footnotetext{
${ }^{36}$ A toponímia local guarda, até hoje, resquícios deste processo de comercialização, como pode ser comprovado por denominações como "Porto Tabuado".

${ }_{37}$ "Discripção...", op. cit., cap. 18.
} 
reiro da capital por navegação costeira (cabotagem), perfazendo de cinco a 10 por cento dos registros de entrada no conselho da cidade (BROWN, 1992:172). De magnitude semelhante eram os portos de Macaé, Campos dos Goytacazes e Cabo Frio.

Feita esta primeira transação, transportava-se a madeira pela Baía de Guanabara ou por cabotagem até a cidade do Rio de Janeiro, onde ela era armazenada nas "estâncias" dispostas ao longo da praia de D. Manoe ${ }^{38}$. Estes pontos de estocagem pertenciam aos grandes negociantes do ramo, então chamados de madeireiros ${ }^{39}$. Na alvorada da época imperial, eram apenas cinco:José Bernardes Monteiro, Antonio José, Francisco Manoel de Faria,José Francisco Diogo e João Pereira de Britto. Em fevereiro de 1825, com a finalidade de barganhar a renovação da licença que lhes havia sido concedida por D. João VI, eles enviam uma representação conjunta ao imperador D. Pedro I, com a seguinte proposta - relatada pelo Intendente Geral da Polícia:

P." conciliarem o publico interesse com a vantagem de obterem hi local espaçoso p. "venda das suas madeiras, propõem-se a aterrarem sobre o mar a m. ${ }^{\text {ma }}$ porção de terreno q. occupão, fazendo o Cães, e terrapleno a sua custa desde o Largo de Moura athe as Cocheiras, com a largura de 150 palmos, pouco m.; ou menos p." Servidão publica, e offerecendo alem disto cada hum dos Sup. gratuitam. cem carradas de pedra p." as rampas das fr." das duas q. deverão ser mandadas construir p. ${ }^{\text {'o }}$ Senado ou Policia. Exigem p." este fim a concessão do terreno q. occupão, e q. pedem se lhes conceda de propried. com 9 a 10 braças de fundo, com as frentes q. atualm. ${ }^{\circ}$ te $\mathrm{m}^{40}$.

O investimento a que se propuseram nos permite aferir um razoável grau de especialização destes comerciantes, um comportamento econômico incompatível com as posições do topo da pirâmide mercantil, conforme demonstrouJoão Fragoso (1992:153-98). De fato, não encontramos nenhum madeireiro com mais de dez mil quilômetros

Atualmente, a extensão de orla que vai desde o mosteiro de São Bento até a Praça XV.

${ }^{39}$ Esta denominação encontra-se em Morales de los Rios Filho (2000: 278).

${ }^{40}$ "Representação assinada por José Bernardes Monteiro e outros negociantes de madeiras, estabelecidos na praia de D. Manoel, dirigida a S.M.I.". Biblioteca Nacional do Rio de Janeiro, Seção de Manuscritos, 11-34, 26, 25. 
no comércio de longa distância (anos de 1812-14, 1817 e 1822), o filé mignon dos negócios coloniais. A transação da madeira entregavam-se mercadores de porte médio, ligados exclusivamente ao comércio de abastecimento interno; se, por um lado, estes indivíduos não eram reles vendeiros, tampouco se aproximavam dos poderosos negociantes imperiais, movimentadores essenciais da economia do mundo luso.

A madeira, em razão de suas características físicas (tamanho e peso, principalmente), era uma mercadoria cujo arranjo do circuito distributivo diferia bastante dos demais produtos rurais de consumo interno. Ao contrário destes, seguia, a partir da captação de produtores dispersos, uma trajetória ininterruptamente crescente de centralização, dispensando uma última fase de descentralização varejista ${ }^{41}$; a venda ao consumidor primário (construtores civis, marceneiros, carpinteiros, sapateiros, etc.) era feita pelos maiores comerciantes do ramo. À medida que se subia na hierarquia mercantil da madeira, a "negatividade" da relação de reciprocidade tendia a crescer exponencialmente (relações capitalistas mercantis), propiciando aos negociantes urbanos - o elo final entre produção e consumo - vultosos lucros.

As madeiras, que são transportadas por conta e risco dos fabricantes para se venderem neste Porto aos negociantes, chegão sempre por hum preço muito módico respeito à aquelle, porque os mesmos negociantes as reputão, e se estes vendem ao povo huma dúzia de taboas de canella preta a razão de $16 \$ Y$, he porque a mesma dúzia lhe ficou posta dentro do seu armazém pelo custo de $8 \$ Y$, e se huma viga he vendida por $4 \$ Y$, he porque lhe custou $2 \$ Y$, de sorte que o negociante quer sempre ganhar cento por cento, e mais se elle pode, e tem occazião de enganar ao comprador ${ }^{42}$.

Outra possibilidade de escoamento, utilizada, sobretudo, pelos produtores de madeira mais pobres, era através do estabelecimento de

${ }^{41}$ R. L. Corrêa (1989: 58) descreve o esquema tradicional de comercialização da produção rural como uma seqüência dispersão-concentração-dispersão: [...] "tanto no começo como no final do processo verifica-se uma dispersão tanto dos produtores rurais como dos consumidores urbanos. Há assim a necessidade de se realizar, próximo à zona rural, a concentração da produção, depois sua transferência para a grande cidade, onde então será de novo dispersa entre os consumidores finais".

${ }_{42}$ Biblioteca Nacional do Rio de Janeiro, Seção de Manuscritos, I-1 1,01, 019, p. 10. 
uma relação regular de trocas com um vendeiro local, permutando madeira - assim como farinha, milho, feijão e arroz - por mantimentos (peças de roupa, pólvora, chumbo, facas, tesouras, etc.) ${ }^{43}$. Conforme ressalta Hebe Mattos de Castro (1987: 79-80), a presença do vendeiro revela um padrão de consumo e articulação econômica integrado exatamente àquele inundo dos "homens livres pobres", ou seja, dos indivíduos que viviam à margem das grandes unidades agrícolas de exportação. Este circuito de troca apresentava-se como mais abrangente em termos dos agentes que dele participavam, alargando as relações de vizinhança ou integrando os habitantes de povoados próximos, nos quais as relações tendiam a ser menos pessoais. Ainda que estas relações fossem baseadas num tipo de reciprocidade que tendia a ser "negativa" - para usar a terminologia clássica desenvolvida por Marshall Sahlins - em face do lucro, ainda que pequeno, retido pelo comerciante, o estabelecimento do crédito, ao garantir o acesso aos bens necessários à sobrevivência, era um elemento essencial na criação de uma interdependência dos vendeiros e seus clientes e a continuidade da relação credor-devedor ${ }^{44}$.

\section{Considerações finais}

O que apresentei neste texto foram apenas alguns prolegômenos à investigação da indústria e do comércio madeireira interno no Rio de Janeiro de fins do período colonial. Neste sentido, as proposições encontradas ao longo do texto devem ser encaradas muito mais como hipóteses a serem testadas do que propriamente como conclusões. Para finalizar este artigo, gostaria, então, de apontar certas direções de pesquisa que entendo como as mais importantes para avançarmos no conhecimento da matéria, que seriam três. Apesar de elas se basearem na minha experiência específica de pesquisa relativa à capitania fluminense, acredito que se apliquem, com alguma boa vontade, a restante do território colonial.

Em primeiro lugar, parece-me fundamental testar a hipótese da complementaridade entre a agricultura itinerante e o extrativismo madei-

"Discripção...", op. cit., cap. 18.

" Este modelo de relações é inspirado nos resultados empíricos encontrados por Delma Pessanha Neves (1981: 114-8). 
reiro de caráter comercial, propiciado pelas condições ecológicas reinantes no ambiente de Mata Atlântica submontana. O esclarecimento desta dinâmica de apropriação silvestre pode contribuir para derrubar o mito da subutilização madeireira, mito este derivado, em larga medida, de uma concepção enviesadamente destrutivista da história florestal brasileira, difundida pela obra de Warren Dean (1996). Se, por um lado, está fora de disputa o resultado final de um modelo de desenvolvimento econômico, por outro, não podemos esquecer que os processos de desflorestamento foram conformados pela ação de indivíduos racionais que buscavam, a partir de seus conhecimentos e expectativas, historicamente circunscritas, acerca do comportamento do ambiente ecológico e dos demais agentes sociais com os quais interagiam, aumentar o grau de previsibilidade e controle sobre o transcorrer intrinsecamente caótico da vida. Afinal de contas, ninguém derruba uma árvore com a intenção primária de tornar seu solo mais erodível e/ou seu rio mais assoreado, pelo menos quando é desta terra que vem o seu alimento e deste manancial, sua água; se árvores são abatidas é porque se espera que algum benefício advenha deste procedimento. Não podemos imputar à cabeça do rurícola colonial dos séculos XVI, XVII e XVIII representações ambientais típicas do século XX - tais como o preservacionis mo. Não importa o quão alto estimemos, a partir de nosso olhar retrospectivo, o custo para o ecossistema e sua biodiversidade; para os homens que estavam em contato com ela, os proventos percebidos superavam os custos percebidos. Este ponto de vista evita certa dose de anacronismo na análise do comportamento ambiental e permite que a historiografia florestal avance para além do fenômeno do desflorestamento e da degradação, para abarcar os processos criativos, de produção e crescimento econômico - e não somente o crescimento organizado pela moderna ciência florestal, mas também aquele, advindo de movimentos anteriores, espontâneos e não-sistemáticos.

Peço licença para abrir um parêntese. Faço absoluta questão de ressaltar que não desejo, com a maneira como acabo de me posicionar, dar alguma sorte de "resposta" possivelmente engendrada pela história econômica à história ambiental, nos moldes sugeridos por Schwartz (2001: 553). Apesar de Peter Burke (1992: 8) interpretar como uma ameaça à "verdadeira" identidade da primeira a emergência da segunda, acreditamos, concordando com a argumentação de Joan Martinez- 
Alier (1995: 165-190), que o que há — ou o que deve haver — é uma recolocação dos problemas ou talvez mesmo uma ampliação do escopo de investigação, propiciada pela aplicação de uma abordagem ecológica ao temário tradicional da histórica econômica. Talvez a melhor descrição de minha abordagem seja fornecida pela expressão "história econômica do ambiente" — cunhada por John Bellamy Foster (1994) - ou, ao contrário, uma "história ambiental da economia". Malabarismos terminológicos à parte, o importante, a meu ver, é não estabelecer "fronteiras tarifárias" ao redor de objetos de estudo e obstruir o fluxo de idéias, o que é tão desnecessário quanto estéril - ensinamento do grande H. C Darby (1953: 9). Fecho o parêntese.

Em segundo lugar, há que se tentar traçar um panorama dos preços das madeiras de construção. O maior problema, aqui, diz respeito às fontes, muito escassas e fragmentadas, além do fato de se apresentarem, muitas vezes, a partir de diferentes unidades de medida (unidade, dúzia e metro cúbico eram as mais usadas). Outro obstáculo refere-se às diferenças esperadas entre os preços "de mercado" e aqueles praticados nas ribeiras e nos arsenais ${ }^{45}$. De qualquer maneira, é bastante provável que o preço das madeiras tenha aumentado significativamente nos anos que se seguiram a partir de dois eventos específicos, a saber, a transferência da Corte portuguesa para o Rio de Janeiro, em 1808 - que provocou um verdadeiro boom na indústria de construção civil, tanto no core urbano como nos seus arrabaldes (BROWN, 1992:166) - e a proibição, por parte do Senado da Câmara, da utilização cio pinho nas edificações da cidade, e m $1819^{46}$.

Ernesto Cruz (1957: 38) informa, por exemplo, que as tábuas e as pranchas paraenses eram vendidas a Lisboa, em 1783 , por um valor que variava de $1 \$ 700$ a $1 \$ 800$ réis a unidade. Francisco Freire Alemão transcreveu um documento de 1792 que relaciona preços, utilizando a unidade de metros cúbicos. Cf. "Inventario geral das madeiras de construção do Brasil". Biblioteca Nacional do Rio de Janeiro, 3,4,30, nº 201.

${ }^{46}$ Alegava-se que os edifícios levantados com a referida madeira eram "instáveis" e "fracos", além de facilmente incendiáveis. Considerava-se, além do mais, que "nem o Publico, nem os Particulares podem experimentar oppressão, ou incoveniencia em consumir ou empregar em lugar das sobreditas madeiras de pinho, as madeiras do pais, pelas quaes se evita interinamente o principal inconveniente [...]". Arquivo Geral da Cidade do Rio de Janeiro, "Minuta de um edital prohibindo o uso de madeiras de pinho", códice 46-2-11, grifo meu. 
Last but not least, seria de se desejar, de bom grado, um estudo prosopográfico sobre este pequeno (pelo menos até o final do primeiro quartel dos oitocentos), mas importante grupo social que era o dos comerciantes de madeira da praça do Rio de Janeiro. Os métodos para tal empreendimento foram, há muito, sistematizados em trabalhos clássicos como os de David Grant Smith (1975) e Rae Jean Dell Flory (1978). Com efeito, este tipo de investigação, ao nos abrir as portas para o universo de sociabilidade destes indivíduos, poderia ajudar-nos a responder perguntas-chave para a compreensão da história socioambiental da indústria madeireira, tais como o papel dos comerciantes no estabelecimento do nível de oferta da madeira, o grau de especialização de suas atividades e o processo de recrutamento para esta "classe" de agentes econômicos, todas estas variáveis possuindo ligação direta com as formas de ocupação e transformação das paisagens das hinterlands rurais.

\section{Referências bibliográficas}

ALMEIDA, Maria R. C. de. Metamorfoses indígenas: identidades e cultura nas aldeias coloniais do Rio de Janeiro. Rio de Janeiro: Arquivo Nacional, 2003. AMADOR, Elmo da Silva. Baía de Guanabara e Ecossistemas Periféricos: Homem e Natureza. Rio de Janeiro: Edição do Autor, 1997.

BARICKMAN, Bert Jude. Um contraponto baiano: açúcar, fumo, mandioca e escravidão no Recôncavo, 1780-1860. Rio de Janeiro: Civilização Brasileira, 2003.

BARTH, Fredrik. Process and Form in Social Life. London: Routlege \& Kegan Paul, 1981.

B R A N N T R OM, Christian."Review of Fruitless Trees".Journal of Latin American Studies 35(1), 2003: 163-214.

_."The Timber Trade in Southeastern Brazil, 1920-1960". Bulletin of Latin

American Research 24(3), 2005: 288-310.

."Was Brazilian Industrialization Fuelled by Wood? Evaluating the Wood

Hypothesis, 1900-1960". Environment and History 1 1, 2(105: 395-4.30.

BRAUDEL, Fernand. Civilização material, economia e capitalismo, sécs. XV-

XVIII. Os jogos das trocas. Lisboa: Edições Cosmos, 1970.

. Civilização material, economia e capitalismo, séculos XV-XVIII.

As estruturas do cotidiano: o possível e o impossível. São Paulo: Martins Fontes, 1997.

B RECHIN, Gray. Imperial San Francisco: Urban Power, Earthly Ruin. Berkeley:

The University of Califórnia Press, 1999. 
B ROWN, LaríssaV. Internal commerce in a colonial society: Rio de Janeiro and its hinterland, 1790-1822. Ph.D. Dissertation. University of Virginia, 1986.

B ROWN, Larissa V. "Urban growth, economic expansion, and deforestation in late colonial Rio de Janeiro". In STEEN, H.K.; T UCKER, R.P. (eds.). Changing tropical forests: historical perspectives on todays challenges in Central and South America. Durham, N.C.: Forest History Society, 1992: 165-175.

BURKE, Peter. Veneza e Amsterdã: um estudo das elites do século XVII. São Paulo: Brasiliense, 1991.

(org). A escrita da história: novas perspectivas. São Paulo: Unesp, 1992.

CABRAL, Diogo de Carvalho. "Produtores rurais e indústria madeireira no Rio de Janeiro do final do século XVIII - evidências empíricas para a região do Vale do Macacu". Ambiente \& Sociedade 7 (2), 2004: 125-143.

CALdeirA, Jorge. A nação mercantilista. São Paulo: Ed. 34, 1999.

CARdoso, Ciro Flamarion S. O trabalho na América Latina colonial. São Paulo: Ática, 1985 .

CASAL, Manuel Aires de. Corografia brasílica. São Paulo: Edições Cultura, 1943 [1817].

CASTRO, Carlos Ferreira de Abreu. "Gestão Florestal no Brasil Colônia".Tese de Doutoramento, inédita. Brasília, DF: UnB, 2002.

CASTRO, Hebe Mattos de. Ao sul da História: lavradores pobres na crise do trabalho escravo. São Paulo: Brasiliense, 1987.

CAVAlCANTi, Nireu. O Rio de Janeiro setecentista: a vida e a construção da cidade da invasão francesa até a chegada da corte. Rio de Janeiro:Jorge Zahar Ed., 2004.

C ORRÊA, Roberto Lobato. A rede urbana. São Paulo: Ática, 1989.

C R O N O N, William. Nature's Metropolis: Chicago and the Great West. Nova York: W.W. Norton and Co., 1991.

CRUZ, Ernesto."A exportação da madeira do Pará para Portugal no século XVIII". R I H G B 234, 1957: $38-43$.

DARBY, Henry Clifford."On the relations ofgeography and history". Transactions and Papers. London: The Institute of British Geographers, publication ${ }^{\circ}{ }^{19}$, 1953: 1-11.

DEAN, Warren. A ferro e fogo: a história e a destruição da Mata Atlântica brasileira. São Paulo: Companhia das Letras, 1996.

DEFFONTAINES, Pierre. "A floresta a serviço do homem no Brasil". Boletim Geográfico 28, 1945:561-568.

DiÉGues Júnior, Manuel. Regiões culturais do Brasil Rio de Janeiro: Centro Brasileiro de Pesquisas Educacionais, 1960.

DRUMMOND), José Augusto. Devastação e preservação ambiental no Rio de Janeiro. Rio de Janeiro: EdUFF; 1997.

"Natureza rica, povos pobres? Questões conceituais e analíticas sobre o papel dos recursos naturais na prosperidade contemporânea". Ambiente \& Sociedade 5 (10), 2002: $45-68$. 
ENGEMANN, Carlos et alii."Consumo de recursos florestais e produção de açúcar no período colonial: o caso do engenho do Camorim, RJ". In OLIVEIRA, Rogério Ribeiro de. (org.). As marcas do homem na floresta: história ambiental de um trecho de Mata Atlântica. Rio de Janeiro: Ed. PUC-Rio, 2005: $119-140$.

FLORY, Rae Jean Dell. Bahian society in the mid-colonial period: the sugar planters, tobacco growers, merchants, and artisans of Salvador and the Recôncavo, 1680-1725. Ph.D. dissertation. Austin: University ofTexas, 1978.

FOSTER, John Bellamy. The vulnerable planet: a short economic history of the environment. New York: Monthly Review Press, 1994.

A ecologia de Marx: materialismo e natureza. Rio de Janeiro: Civilização Brasileira, 2005.

FRAGOSO,João. Homens de grossa aventura: acumulação e hierarquia na praça mercantil do Rio de Janeiro (1790-1830). Rio de Janeiro: Arquivo Nacional, 1992.

FRAGOSO,João;FLORENTINO, Manolo. O arcaísmo como projeto: mercado atlântico, sociedade agrária e elite mercantil em uma economia colonial tardia: Rio de Janeiro, C.1790-C.1840. 4* ed. Rio de Janeiro: Civilização Brasileira, 2001.

FR A NÇA, Jean Marcel Carvalho. Visões do Rio de Janeiro colonial: antologia de textos (1531-1800). Rio de Janeiro: EdUERJ, 1999.

FRIDMAN, Fania. Donos do Rio em nome do Rei: uma história fundiária da cidade do Rio de Janeiro. Rio de Janeiro: Jorge Zahar Ed., 1999.

FRIEDRICH,Ernst."Wesen und Geographische der'Raubwirtschaft"'.Petermanns Mitteilungen 50,1904: 68-79/92-95.

FURTADo, Celso. Formação econômica do Brasil. 14 ${ }^{\mathrm{a}}$ ed. São Paulo: Editora Nacional, 1976.

GANDY, Matthew. Concrete and Clay: Reworking Nature in New York City. Cambridge: MIT Press, 2002.

GEORGE, Pierre. Geografia econômica. $2^{*}$ ed. Rio de Janeiro: Fundo de Cultura, 1963.

G O R E N D ER, Jacob. O escravismo colonial. 3“ed. São Paulo: Ática, 1980.

Greenhalgh, Juvenal. O Arsenal de Marinha do Rio de Janeiro na História (1763-1822). Rio de Janeiro: Editora A Noite, 1951.

GRENDI, Edoardo."Repensar a micro-história?" In REVEL,Jacques (org.). Jogos de escalas: a experiência da microanálise. Rio de Janeiro: FGV, 1998: 251-262.

HOLANDA, Sério Buarque de. Raízes do Brasil. 26" ed. São Paulo: Companhia das Letras, 1995.

HOLDSWORTH, Andrew; UHL, Christopher."Fire in Amazonian selectively logged rain forest and the potential for fire reduetion". Ecological Applications 7 , 1997: $713-725$.

KAUTSKY, Karl. A questão agrária. São Paulo: Proposta Editorial, 1980.

KOEHLER, Arthur. The Properties and Uses of Wood. Nova York: McGraw-Hill Book Company, 1924. 
LAMEgo, Alberto Ribeiro. O homem e a Guanabara. $2^{a}$ ed. Rio de Janeiro: Conselho Nacional de Geografia, 1964.

LAPA, J. R. do Amaral. A Bahia e a carreira da Índia. São Paulo: Editora Nacional, 1968.

LAVRADIO, Marquês de. "Relação"- parte II. RIHGB 76, 1946 [1779]: 289-360.

LEANDRO, José Augusto. "Devastação e tráfico de madeira no litoral do Paraná provincial". Revista de História Regional 4 (2), 1999: 93-105.

LEÃO, Regina Machado. A floresta e o homem. São Paulo: Editora da Universidade de São Paulo, 2000.

LUCCOCK, John. Notas sobre o Rio de Janeiro e partes meridionais do Brasil. São Paulo: Martins, 1951 .

MARTINEZ-ALIER, Joan. De la economia ecológica al ecologismo popular. Montevidéu: Editorial Nordan-Comunidad, 1995.

MAURO, Frédéric. Portugal, o Brasil e Atlântico (1570-1670). Lisboa: Editorial Estampa, 1989.

"Merchant communities, 1350-1750". In TRACY, James D. (ed.). The

Rise of Merchant Empires: Long-Distance Trade in the Early Modern World, 1350-1750. Cambridge: Cambridge Umversity Press, 1990: 255-286.

MEDINA, Gabriel."Ocupação cabocla e extrativismo madeireiro no Alto Capim: uma estratégia de reprodução camponesa". Acta Amazônica 34 (2), 2004: 309-18.

MerleaU-POnty, Maurice. A natureza. São Paulo: Martins Fontes, 2000.

MILLER, Shawn William. Fruitless trees: portuguese conservation and Brazil's colonial timber. Stanford: Stanford University Press, 2000.

MONTEIRO,A.L.S. et alii. "Impactos da exploração madeireira e do fogo em florestas de transição da Amazônia Legal". Scientia Forestalis 65, 2004: 11-21.

MORALES DE LOS RIOS FILHO, Adolfo. O Rio de Janeiro imperial. 2* ed. Rio de Janeiro:Topbooks, 2000.

MORAN, Emilio F. Adaptabilidade humana: uma introdução à antropologia ecológica. São Paulo: EDUSP, 1994.

MORTON, F.W.O."The Royal Timber in Late Colonial Bahia". Hispanic American Historical Review 58 (I), 1978:41-61.

MUMFORD, Lewis. "The Natural History of Urbanization". In THOMAS, W.L.J. (ed.). Man's Role in Changing the Face of the Earth.Vol. 1. Chicago:The University of Chicago Press, 1956: 382-398.

NEVES, Delma Pessanha. Lavradores e pequenos produtores de cana: estudo das formas de subordinação dos pequenos produtores agrícolas ao capital. Rio de Janeiro: Zahar Editores, 1981.

PEDREIRA, Jorge Miguel Viana. Os homens de negócio da praça de Lisboa de Pombal ao vintismo (1755-1822): diferenciação, reprodução e identificação de um grupo social. Lisboa: Faculdade de Ciências Sociais e Humanas, Universidade Nova de Lisboa, 1995. 
PERLIN, John. História das florestas: a importância da madeira no desenvolvimento da civilização. Rio de Janeiro: Imago, 1992.

POLANYI, Karl. A grande transformação: as origens de nossa época. $2^{\star}$ ed. Rio de Janeiro: Campus, 2000.

PR A D O JÚ N I R, Caio. Formação do Brasil contemporâneo. 9“ ed. São Paulo: Brasiliense, 1969.

ROBERTSON, Ross M. História da economia americana. Rio de Janeiro: Record, 1967.

RODRIGUES, Jaime. "Arquitetura naval: imagens, textos e possibilidades de descrições dos navios negreiros". FLORENTINO, Manolo (org.). Tráfico, cativeiro e liberdade (Rio de Janeiro, séculos XVII-X1X). Rio de Janeiro: Civilização Brasileira, 2005: 79-123.

SAint-Hilaire, Auguste de. Segunda viagem do Rio de Janeiro a Minas Gerais e a São Paulo. Rio de Janeiro: Companhia Editora Nacional, 1932.

.Viagem pelos distritos dos diamantes e litoral do Brasil. Belo Horizonte: Ed. Itatiaia, 1974.

SCHMIDT, Carlos Borges. Técnicas agrícolas primitivas e tradicionais. Brasília, DF: Conselho Federal de Cultura e Departamento de Assuntos Culturais, 1976.

SCHWARTZ, Stuart B., "Review Fruitless Trees".Journal of Economic History $61(2), 2001: 552-553$.

SELDON, Arthur; PENNANCE, F.G. Dicionário de economia. 2* ed. Rio de Janeiro: Edições Bloch, 1975.

SMith, David G. The mercantile class of Portugal and Brazil in the seventeenth century: a socio-economic study of the merchants of Lisbon and Bahia, 1620-1690. Ph.D. dissertation. Austin: University of Texas, 1975.

SOFFIATI, Arthur. "Destruição e proteção da Mata Atlântica no Rio de Janeiro: ensaio bibliográfico acerca da eco-história". História, Ciências, Saúde Manguinhos IV (2), 1997: 309-328.

SOUZA, Paulo Ferreira de. Indústria madeireira. Rio de Janeiro: Imprensa Nacional, 1947.

THOMPSON, Edward P. Senhores e caçadores. $2^{\star}$ ed. Rio de Janeiro: Paz \&Terra, 1987.

VON IHERING, Hermann. "Os machados de pedra dos índios do Brasil e o seu emprego na derrubada das matas". Revista do Instituto Histórico e Geográfico de São Paulo XIII, 1908:426-433.

WENTZ, Liliane I.M. Os caminhos da madeira: região norte do Rio Grande do Sul (1902-1950). Passo Fundo-RS: Editora da Universidade de Passo Fundo, 2004. WILliams, Michael. Deforesting the earth: from pre-history to global crises. Chicago: The University of Chicago Press, 2003.

WORSTER, Donald."History as natural history: An essay on theory and method". Pacific Historical Review 53 (1), 1984: 1-19. 


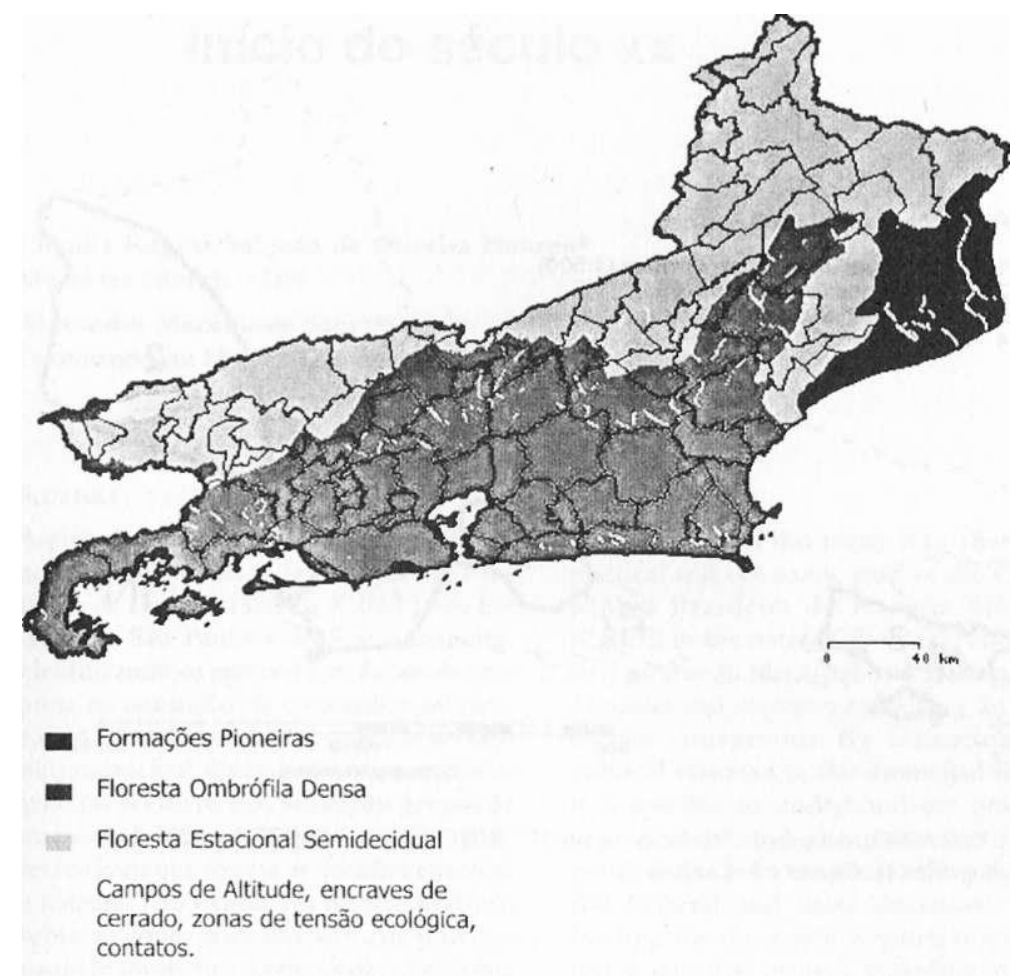

Fonte: FUNDAÇÃO SOS MATA ATLÂNTICA. Atlas dos Municípios da Mata Atlântica. < $\underline{\text { http:// }}$ www.sosiiiatatlantica.org.br/?secao=at]as $>$ 


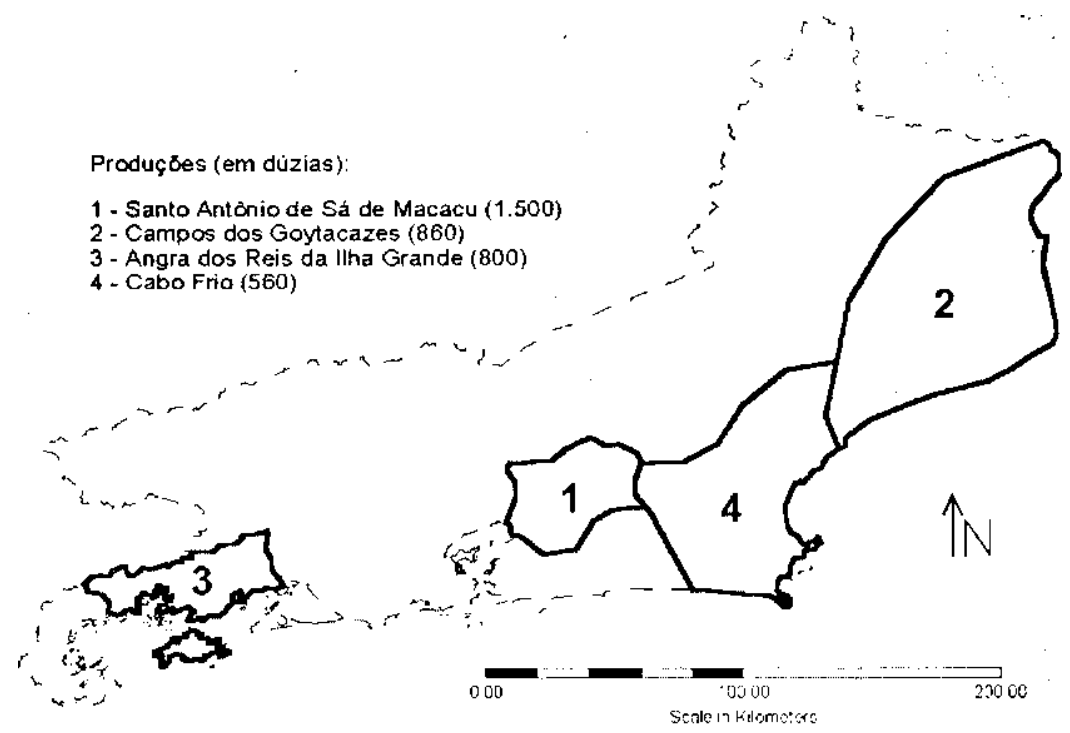

Fonte: LAVRADIO, Marquês de."Relação - parte II". RIHGB, v.76, 1946 [1779], pp.289-360. Base cartográfica: R. Chaves e A. Cardoso. 